СТУДИЈЕ И РАСПРАВЕ

Дојчил П. Војводић

Универзитет у Новом Саду

Филозофски факултет

Одсек за славистику

vojvodicd@ff.uns.ac.rs
УДК 811.163.41'366.58'38: 811.161.1'366.58'38

https://doi.org/10.18485/slavistika.2019.23.1.1

оригинални научни рад примљено 14.05.2019.

прихваћено за штампу 16.05.2019.

\title{
О ВИДСКО-ВРЕМЕНСКОЈ СИНОНИМИЈИ И МЕТАФОРИ У СРПСКОМ, РУСКОМ И ДРУГИМ СЛОВЕНСКИМ ЈЕЗИЦИМА*
}

У раду (на материјалу српског, руског и других словенских језика) се са конфронтативног аспекта разматра функционисање морфолошки међусобно супротстављених категорија свршеног (CB) и несвршеног вида $(\mathrm{CB})$ у једним те истим синтаксичким позицијама, односно у истом или сличном видском (видско-временском) контексту. Скреће се пажња да је могућност узајамне замјене (конкуренције, синонимије) вида општесловенска карактеристика, али и да нису сви словенски језици у стању да једнозначно и у истој мјери синтаксички изразе дату супротстављеност јер једни језици (сјевернословенски и словеначки) имају већу слободу видске супституције, док је код друих (јужнословенских, укључујући и српски) та могућност у неким случајевима веома ограничена или је чак потпуно одсутна. Указује се такође на чињеницу да се анализирана појава чешће може срести код употребе индикативних (претериталних, презентских и футуралних) него код употребе неиндикативних форми (императива, кондиционала и инфинитива). Поред видске конкуренције, гдје се СВ и НСВ готово равноправно међусобно замјењују, посебна пажња поклања се и другим сличним појавама, прије свега, неутрализацији видске опозиције (која је нарочито карактеристична за руски језик) повезаној са видско-временском транспозицијом (метафоричким ширењем семантике и повећањем броја функција НСВ на рачун СВ).

Кључне ријечи: синонимија (супституција, међусобна замјена, конкуренција) СВ и НСВ, видско-временска транспозиција (метафора), видска неутрализација, српски, руски и други словенски језици, конфронтативни аспекат.

The paper considers - from a contrastive aspect (on material from Serbian, Russian and other Slavic languages) - the functioning of the morphologically opposed categories of the perfective (PF) and imperfective aspect (IPF) in same syntactic positions, that is, in the same or similar aspectual (aspectual-temporal) context. Special attention has been paid to the possibility of aspect interchange (competition, synonymy) as a pan-Slavic characteristic, but also to the fact that not all Slavic languages are able to express the given opposition in a single meaning and to the same

* Овај прилог настао је у оквиру научних пројеката № 178021 („Опис и стандардизација савременог српског језика”) и № 178002 („Језици и културе у времену и простору”), које финансира Министарство просвете, науке и технолошког развоја Републике Србије.

Рад преставља интегралну верзију реферата прочитаног (под насловом „Проблема конкуренции, нейтрализации и транспозиции вида и времени в сербском, русском и других славянских языках в сопоставительном аспекте") на XVI међународном конгресу слависта (у оквиру засједања Комисије за аспектологију Међународног комитета слависта одржаног 23. августа 2018. године) у Београду. Пошто је одређени круг питања из дате области већ био предмет наше анализе (в., поред осталог, Војводић 1989; 2003; Войводич 1998а: 122-124; 2008), ми поједине аспекте, иако су непосредно везани за назначену тему, нећемо разматрати детаљно, већ само у оној мјери у којој је то неопходно за додатну потврду садашњим испитивањем добијених података и релевантних закључака о различитим могућностима употребе анализираних форми. Такође и егземплификација, као и литература о датој теми, наводи се у чланку селективно.

Славистика XXIII/1 (2019) 
extent, because some languages (North Slavic and Slovenian) have greater freedom of aspect substitution, while in others (South Slavic, including Serbian) that possibility is very limited or even completely absent in some cases. The paper also points to the fact that the analyzed phenomenon can be seen more often in the use of indicative forms (preterite, present and future) than in the use can be seen more often in the use of indicative forms (preterite, present and future) than in the use
of non-indicative forms (imperative, conditional and infinitive). Besides aspectual competition, where PF and IPF are almost reciprocally interchangeable, special attention is also given to other similar phenomena, above all the neutralization of aspectual opposition (which is a specific quality of the Russian language) related to aspectual-temporal transposition (metaphorical expansion of semantics and increase in the number of functions of IPF at the expense of PF)

Key words: synonymy (substitution, interchange, competition) of PF and IPF, aspectual-temporal transposition (metaphor), aspectual neutralization, Serbian, Russian and other Slavic languages, contrastive aspect.

\section{1. Уводне напомене}

Диференцијација свршеног и несвршеног глаголског вида (у даљњем тексту СВ и НСВ), чија употреба обилује разноврсним корелацијама, представља једну од најважнијих и најуочљивијих карактеристика словенског глаголског система заснованог на принципу бинарне опозиције. Тај аспекат датих категорија посебно долази до изражаја на синтаксичком нивоу, а прије свега у случајевима када се један вид замјењује другим - њему супротстављеним - видом у истом или сличном видском (видско-временском) контексту. У аспектолошким истраживањима ти односи замјене обично се своде на сљедећа три основна типа видске супституције (в., нпр.: Бондарко 1962; 1971a: 36-42):

1.1. када је међусобна замјена СВ и НСВ немогућа, јер у том случају модификовани исказ постаје видски бесмислен и неправилан, као, нпр., у сљедећим исказима и њиховим видским модификацијама; уп.: (1а) (срп.) У том тренутку Марко је нагло отворио (СВ) врата, због чега се Милан уплашио

*У том тренутку Марко је нагло отварао (НСВ) врата, због чега се Милан плашио

(2а) (срп.) Свуноћ те тражимо (НСВ), гдје си то, о Косто? (Лалић 1975)

* Свуноћ те нађемо (CB), гдје си то, о Косто? (CB) и паo (CB) ( $\mathrm{HCB})$ и падао (НCB). (1б) (рус.) В тот момент Марко внезапно открыл (СВ) дверь, из-за чего Милан испугался (СB) и (СВ) упал.

*B тот момент Марко внезапно открывал (НСВ) дверь, из-за чего Милан пугался (НСB) и падал (НСB).

(2б) (рус.) Мы тебя целую ночь ище-ем (НСВ), где ты, эй, Косто-о? (Лалич 1976).

* Мы тебя целую ночь найдем (СВ), где ты, эй, Косто-о?
Примјери (1a) и (16) показују да НCB није могуће употребити умјесто СВ јер би значење трајне, односно итеративне радње, које би се реализовало употребом НCB, противурјечило како лексичким елементима контекста (у тол тренутку, нагло) тако и укупном контексту, односно ситуацији. Слично је и у примјерима (2a) и (2б), гдје контескт уопште не допушта употребу СВ умјесто НСВ. Та немогућност замјене остаје без обира на лексичко-семантички тип глагола и врсту глаголске радње, као и без обзира на то да ли се $\mathrm{HCB}$, односно CB образује помоћу префикса или суфикса (као у примјерима (1а) и (1б)), или пак лексички - помоћу суплетивне форме (као у примјерима (2a) и (2б)). Другим ријечима, контекст је тај који допушта или не допушта такву могућност;

1.2. када је замјена једног вида другим видом могућа, с тим да се у том случају мијења смисао исказа, као, на примјер, у временским реченицама с везником када или у контексту (реченицама) прошле итеративне радње; уп. (3а) (срп.) Управо када сам улазио (НСВ) у кућу, сручио се пљусак.

Управо када сам ушао (CB) у кућу, сручио се пљусак.

(4a) (срп.) 3acmajao (HCB) caм крај потока, припитивао (НСB) нешто малога Зара, зборио (НСВ) јасно да ме и момче чује (Вуковић 1959).

Застао (СВ) сам крај потока, припитао (CВ) нешто малога Зара, прозборио (СВ) јасно да ме и момче чује. (3б) (рус.) Именно когда я входил (НСB) в дом, хлынул ливень.

Именно когда я вошел (СВ) в дом, хлынул ливень.

(4б) (рус.) Я останавливался (НСB) возле ручья, спрашивал (НСB) что-то мальчика Заро, говорил (НСВ) ясно, чтобы и парень услышал меня (наш перевод - Д.В.).

Я остановился (СВ) возле ручья, спросил (СВ) что-то мальчика Заро, внятно сказал ('заговорил') (СВ), чтобы и парень услышал меня.
Уз тип видског односа, какав је у датим примјерима, можемо додати сљедећи кратки коментар. Наиме, када се у првом дијелу реченица (3а) и (3б) умјесто НСВ (улазио / входил) употреби СВ (ушао / вошел), онда се мијења релативно-временски, односно таксисни смисао исказа јер се у том случају друга радња (сручио / хльннул), за разлику од њеног значења у наведеном исказу-реченици, гдје се она реализује за вријеме трајања прве радње (улазио / входил), реализује тек послије завршетка прве радње (ушао / вошел). За исказе (4а) и (4б) треба рећи да промјеном вида (НСВ у СВ) радња престаје да буде итеративна, односно да се том промјеном може изразити само једнократна радња;

Славистика XXIII/1 (2019) 
1.3. када је међусобна замјена СВ и НСВ могућа, тако да се не мијења основни смисао исказа, већ само његове одређене прагматичко-стилске нијансе, нпр., у императивним реченицама-исказима: (5а) (срп.) Шаљи (НСВ) жене или кога хоћеш, не знам ја коме ко дугује (Лалић 1975).

Почази (СВ) жене или кога хоћеш, не знам ја коме ко дугује. (5б) (рус.) Посылай (НСВ) женщин, посылай (НСB) кого хочешь, я уж сбился, кто у кого в должниках тут ходит (Лалич 1976).

Пошли (СВ) женщин, пошли (СВ) кого хочешь, я уж сбился, кто у кого в должниках тут ходит
Наведена два исказа у (5а) у српском језику разликују се само с обзиром на степен учтивости; први исказ (НСВ) представља категоричко, грубље, односно мање учтиво или нетолерантно обраћање адресанта адресату, а други (CB) блаже, учтиво обраћање са одређеним степеном толеранције. Додајмо да руски еквиваленти у (5б) функционишу обрнуто - императивом НСВ изражава се учтиво, толерантно обраћање, а императивом CВ - категоричко, грубље или нетолерантно обраћање (о избору и функционисању императива СВ и НСВ у руском и другим словенским језицима на прагматичком плану в. посебно Benacchio 2002, 2010).

Ми ћемо се овдје посебно задржати на анализи неких примјера који би се могли сврстати управо у овај посљедњи (1.3) тип видских односа, а који се у лингвистици, почев от В. Матезиуса (Mathesius 1947), најчешће разматра као видска конкурениија (уп., поред осталог, Bareš 1956; Бондарко 1962; Kř́žkovă 1961, 1965; Петрухина 1976, 1978; Гуляницкий 1978; Ivić 1983; Шведова 1984; Israeli 1996, 1998; Падучева 1996: 53-65; Борисова 1997; Војводић 2003, 2008; Grønn 2006; Гренн, Филюшкина Краве 2007; Тху Ха 2014; Воронец 2015; уп. такође Ивић 1958; Бондарко 1971a: 36-42, 226-234; Rassudova 1984: 41-43, 93 97; Черткова 1996; Петрухина 2000; Гловинская 2001; Плунгян 2003).

I УП. такође Tošović 2001: 29-37, гдје аутор, анализирајући појам конкуренције у језику, констатује да ова појава као лингвистички термин у досадашњим језичким истраживањим није била посебно разматрана, усљед чега није у довољној мјери разграничена од других сличних појава, као што су корелација, опозиција, неутрализација, транспозиција, синкретизам, синонимија, интеракција, супституција и сл., па, према томе, ни ваљано дефинисана. Он сматра да дати појам и термин, који се врло често користио у досадашњим језичким анализама, представља, заправо, или избор, или синонимију, или замјену, истичући да дефиниција конкуренције мора да подразумијева постојање асиметије, која се, по правилу, састоји најмање од три компоненте (корелата) - оријентира, с једне стране, и обично двије (али поодносу на нега, с труге стране. Без обзира на могуће прелности овакве диференцијачије и дефинищије датога појма, односно термина, ми ћемо га овдје, ипак, користити у оном смислу у којем је досада најчешће употребљаван - у значењу супституције (замјене), односно синонимије граматичких категорија међусобно супротстављених на морфолошком, али компатибилних на синтаксичком нивоу.

\section{2. Видска конкуренција као синонимија глаголских облика}

Појаву видске конкуренције у словенским језицима могуће је запазити код свих глаголских облика без обзира на временски или модални план у ком се они употребљавају. Могућност конкуренције најчешће се везује за индикативне облике, тј. за употребу претериталних, презентских и футурских облика. Посебну улогу у овој појави имају презентски облици СВ и НСВ, којима се исказују различити аспекти апстрактне садашњости, као и прошле итеративне и будуће радње, које се исказују њиховом транспозицијом. Исто тако конкуренција је могућа у употреби неиндикативних облика (начина) - императива, потенцијала или инфинитива (чије ћемо разматрање, због ограниченог простора, овом приликом изоставити). Навешћемо и проанализирати више примјера који илуструју неке од споменутих случајева дате појаве.

2.1. Видска конкуренција у контекстима са индикативним облицима.

2.1.1. Примјери са претериталним облицима:

(6а) (срп.) Да ли си прочитао (СВ) роман Ф. М. Достојевског «Злочин и казна»?

Да ли си читао (НСВ) роман Ф. М. Достојевског «Злочин и казна»?

Уп. исти примјер у руском и пољском језику: (6б) (рус.) Ты прочитал (СВ) роман Ф. М. Достоевского «Преступление и наказание»?

Ты читал (НСВ) роман Ф. М. Достоевского «Преступление и наказание»? (6в) (пољ.) Czy przeczytateś (CB) powieść F. M. Dostojewskiego «Zbrodnia i kara»?

Czy czytateś (HCB) powieść $\mathrm{F}$ M. Dostojewskiego «Zbrodnia i kara»?
Треба истаћи да претеритални облици СВ и НСВ у наведеним пријерима (6a) - (6в) не представљају апсолутне, међусобно „конкуретне“, замјенљиве синониме јер СВ у датом случају има конкретно-фактичко значење, а НCВ - општефактичко иако су међу њима разлике једва примјетне (уп. Маслов 2004: 72, 104; Петрухина 2008). ${ }^{2}$

2.1.2. Значајну улогу у супституцији имају презентски облици СВ и НСВ помоћу којих се изражавају различити аспекти апстрактне (неактуелне) садашњости. Уп., нпр., употребу датих облика у пословицама (тзв. гномски презент):

(7а) (срп.) Паметнији (увијек) попушта (НСB). Паметнији (увијек) попусти (СB).

${ }^{2}$ У одричном контексту НСВ може да реализује и значење готово изједначено са конкретно-фактичким значењем СВ, усљед чега долази до појачане видске конкуренције (више томе в., поред осталог, Падучева 2008; Мелиг 2015).

Славистика XXIII/1 (2019) 
(8a) (срп.) Кад Бог хоће кога да казни, најприје му узме (CB) памет.

Кад Бог хоће кога да казни, најприје му узима (НCB) памет

УП. исте примјере у руском и пољском језику:

\begin{tabular}{|c|c|}
\hline $\begin{array}{l}\text { (7б) (рус.) Умный всегда yступает } \\
\text { (НСB). }\end{array}$ & $\begin{array}{l}\text { (7в) (пољ.) Mądry głupiemu ustępuje } \\
\text { (НСB). }\end{array}$ \\
\hline Умный всегда уступит (СВ). & Mądry głupiemu ustapi (CB). \\
\hline $\begin{array}{l}\text { (8б) (рус.) Кого Бог захочет } \\
\text { наказать, того лииит (CB) } \\
\text { разума. }\end{array}$ & $\begin{array}{l}\text { (8в) (пољ.) Kogo Bóg chce skarać, } \\
\text { temu rozum odejmie / odbierze } \\
\text { (CВ). }\end{array}$ \\
\hline $\begin{array}{l}\text { Кого Бог захочет наказать, } \\
\text { того лишает (НСВ) разума. }\end{array}$ & $\begin{array}{l}\text { Kogo Bóg chce skarać, temu } \\
\text { rozum odejmuje / odbiera } \\
\text { (HCB). }\end{array}$ \\
\hline
\end{tabular}

Уп. такође сљедећу српску пословицу и њене еквиваленте у руском, польском, чешком и словачком (у којима се, као и у осталим сјеверноловенским језицима, презентски облици СВ најчешће употребљавају као граматикализовани облици футура СВ), као и у словеначком језику (тј. једином јужнословенском језику, у којем презент СВ може да има, премда само понекад - у специфичном контексту - „Право“ футурско значење):

(9а) Ко другому јаму копа сам у њу пада (НСB).

Ко другому јаму копа сам у њу падне (СВ) / сам ће у њу пасти (футур СВ).

(9б) (рус.) Кто другому яму копает, тот сам в нее попадает (НСB). ${ }^{3}$

Кто другому яму копает, тот сам в нее попадет (CB).

(9в) (пољ.) Kto pod kim dołki kopie, sam w nie wpada (HCB).

Kto pod kim dołki kopie, sam w nie wpadnie (CB)

(9Г) (чеш.) Kdo jinému jámu kopá, sám do ní padá (HCB).

Kdo jinému jámu kopá, sám do ní padne (CB).

(9д) (словач.) Kto inému jámu kope, sám do nej padá (НCB).

Kto inému jámu kope, sám do nej padne (CB).

${ }^{3}$ Уп. варијанту, у којој је у зависном дијелу реченице употребљено 2. л. јд. одричног облика императива, а у главној - 2. л. јд. перфективног презента (облика будућег времена СВ), који се не подвргава супституцији имперфективним презентом (или обликом футура НСВ): Не рой другому яму, сам в нее попадешь $(\mathrm{CB})\left[{ }^{*}\right.$ Не рой другому яму, сам в нее попадаешь будешь попадать $(\mathrm{CB})]$.

Славистика XXIII/1 (2019)
О видско-временској синонимији и метафори у српском, руском и другим.

(9ђ) (словенач.) Kdor drugemu jamo koplje, sam vanjo pada (HCB).

Kdor drugemu jamo koplje, sam vanjo pade (CB).

УП. еквиваленте наведеног примјера у бугарском и македонском језику, у којима се имперфективни презент не може као у српском замијенити перфективним презентом већ је то могуће постићи само футуром СВ (који, као аналитички облик, садржи и перфективни презент):

(9е) (буг.) Който копае гроб другиму, сам пада (НСB) в него.

Който копае гроб другиму, сам *падне (CB) / ще падне (футур СВ) в него.

(9ж) (мак.) Кој копа јама, самиот паѓ $(\mathrm{HCB})$ во неа.

Кој копа јама, самиот *падне (СВ) / ќе падне (футур СВ) во неа.

2.1.2.1. За све словенске језике карактеристично је изражавање апстрактне итеративне садашњости облицима презента НCB и СВ и у другим типовима контекста, као нпр. у ситуацијама вршења свакодневне, уобичајене радње, или пак радње којом се указује на способност њеног вршиоца и сл. УП. у срп. јез:

(10) Свако јутро устанем (CB), умијем се (CB) и одем (CB) на посао.

Свако јутро устајем (НСB), умивам се (НСB) и одлазим (НСB) на посао.

УП. сличне примјере у руском, пољском и чешком језику, гдје се, као и у примјерима (7а) - (9ж), у „конкурентним“ / синонимичним односима налазе презентско-имперфективни (НСB) и презентско-перфективни, односно презентско-футурски (СВ) облици:

(11) (рус.) По его завету мы и поступаем... Всего у нас вдоволь. Осенью наварим (CB) браги, такой крепкой - обруча на бочках трещат, да и выпьем (CB) за твое, государь, здоровье (Толстой 1946).

По его завету мы и поступаем... Всего у нас вдоволь. Осенью навариваем (HCB) браги, такой крепкой - обруча на бочках трещат, да и выпиваем (НСВ) за твое, государь, здоровье.

(12) (пољ.) Zaledwie kilka wierszy druku, rzuci się (CB) na nie okiem, przeczyta (CB), potem przejdzie (CB) do innych wzmianek i artykułów, gazetę się schowa (CB) lub spali (CB) i na tem koniec! (Кошмидер 1934).

Zaledwie kilka wierszy druku, rzuca się(HCB) na nie okiem, czyta / przeczytuje<! > (HCB), potem przechodzi (HCB) do innych wzmianek i artykułów, gazetę się chowa (HCB) lub pali (HCB) i na tem koniec!

Славистика XXIII/1 (2019) 
18

(13) (чеш.) Vždycky tam dostanu (CB) čaj s malinovou št’ávou a sladké koláčky (Петрухина 1983).

Vždycky tam dostávám (HCB) čaj s malinovou št'ávou a sladké koláčky.

(14) (чеш.) Vypije (CB) dvě sklenice piva denně (Bareš 1956).

Pije (HCB) dvĕ sklenice piva denně.

2.1.3. За актуелну садашњост и говорни тренутак везују се одређени случајеви исказивања апстрактне итеративне садашњости, гдје се преферира употреба CВ. Паралелно са датим, већ добро познатим у лингвистици, примјерима употребе СВ навешћемо и њихове „конкурентне“ модификације са НСВ. У русистици је најчешће навођен сљедећи (понекад синтаксички и лексички модификован) примјер:

(15) Посмотрите, что делает заяц: то вскочит (СВ), то ляжет (СВ), то перевернется (СB), то пдымет (CB) уши, то прижмет (СВ) их (Бондарко 1971a).

Посмотрите, что делает заяц: то вскакивает (НСB), то ложится (НСВ), то переворачивается (НСB), то пдымает (НСВ) уши, то прижимает (НСB) их.

У србистици се такође наводи сличан тип употребе СВ:

(16) Види, види ... Искидани облаци лете, застру (СВ) месец, опет га открију (CB), и зато што облаци хитају, чини ми се да месец јури (Стевановић 1969).

Види, види ... Искидани облаци лете, застиру (НСВ) месец, опет га откривају (НСВ), и зато што облаци хитају, чини ми се да месец јури.

Поредећи напоредну употребу СВ и НСВ у наведеним примјерима синтаксичке (контекстуалне) итеративности, можемо примијетити да њихова видска значења нису апсолутно синонимична, односно да $\mathrm{HCB}$, ипак, не покрива у потпуности видску вриједност СВ, јер НСВ садржи компоненту процесуалности, за разлику од $\mathrm{CB}$, који се одликује једнократношћу радњи конкретно-типичног значења (уп. примјере итеративне радње у историјском презенту у тачки 3.1.2). ${ }^{4}$

${ }^{4}$ Овакав тип употребе СВ (перфективног презента) анализиран је и интерпретиран на различите начине како у русистици тако и у србистици. Тако, на примјер, по К. С. Аксакову (1855: 10) се перфективним облицима у примјеру (15) изражавају атемпоралне радње (јер се овај исти глаголски облик често употребљава на сва три временска плана, што указује да није временски маркиран), док се према А. М. Пешковском (2001: 126-127) и И. К. Буњиној (Бунина 1959: 156-157) ради о актуелној, односно конкретној садашњости (jер се СВ реализује у говорном тренутку, односно контексту актуелне садашњости, изражене презентом НСВ - по-
О видско-временској синонимији и метафори у српском, руском и другим.

2.1.4. Поред наведених случајева конкуренције СВ и НСВ могу се срести и други случајеви дате појаве којима се одликују словенски језици. Овдје мислимо, прије свега, на могућност да се НСВ ,једносмјерно“ замјени СВ, чему језичка пракса врло често даје предност. Навешћемо само најкарактеристичније случајеве такве употребе СВ, која се, као и у претходном (2.1.3) случају, обично веже за исказивање актуелне садашњости, односно за говорни тренутак - као полазну тачку на основу које се одређују сви темпорални односи.

2.1.4.1. У лингвистичким испитивањима посвећеним овој проблематици посебно мјесто припада употреби презента СВ у негативним питањима (више о томе в., поред осталог, у Musić 1913; Белић 1973: 131-132; Стевановић 1969 : 568-569; Бондарко 1971a: 110-111; Rassudova 1984: 123-124; Vojvodić 1988 : 50-52; Войводич 2000: 169-170, 2015a; Танасић 1996: 169-170; Ivić 1997: 121-126). Као модел такве употребе СВ најчешће је навођен сљедећи тип упитног исказа:

(17a) (За)што не дођеш (CB)?

УП. еквиваленте датог примјера у другим словенским језицима:

(17б) (рус.) Почему ты не придешь?; (укр.) Чому ти не прийдеш? ; (белорус.) Чаму ты не прыйдзеш? ; (польск.) Dlaczego nie przyjdziesz? ; (чешск.) Proč ne přjjdeš? ; (словацк.) Prečo neprídeš? ; (словен.) Zakaj ne prideš? ; (болг.) Защо не дойдеш? ; (мак.) Зошто не дојдеш?

Иако се употреба перфективног презента у датом исказу на први поглед подудара у свим словенским језицима, ипак постоје одређене нијансе којима се одликују сјевернословенска и јужнословенска употреба датог облика. Као илустрацију тога уп. доленаведене семантичке компоненте, од којих се састоји дати исказ у српском и руском језику.

Употреба српског перфективног презента, који, за разлику од руског (сјевернословенског и, донекле, словеначког) перфективног презента, нема обиљежја граматикализованог глаголског облика, може се семантички представити на сљедећи начин:

смотрите, что делает заяи), а према А. В. Бондарку (1971a: 220-223) овај тип употребе СВ представљь неактуелну (апстрактну, нелокализовану, модалну) садашњост (јер се на актуел(посмотрите, что делает заяи) односи читава свеукупност чинова понављања низа радњи, а не сваки, појединачно узет, акт радње, који, заправо, представља само испољавање сталне способности субјекта да (из)врши одређену радњу у било ком тренутку, па и у говорном ренутку адресанта, као и у времену његовог посматрања датих једнократних радњи-чинова, чиме он доприноси њиховој актуелизацији). За српски примјер М. Стевановић (1969: 574), у складу са Белићевим погледима на сличан тип употребе СВ и теоријом индикатива и релатива, каже да нема значење праве садашњости, односно индикативног презента, већ значење релативног квалификативног презента (јер се радње у исказу само понављају (неодређен број пута) у тренутку говорења). Ми се такође приклањамо оваквој интерпретацији А. В. Бондарка и М. Стевановића (в., поред осталог, Војводић 1988, 2001).

Славистика XXIII/1 (2019) 
20

Дојчил П. Војводић

(18a) Зашто / што не дођеш? : (1) ‘дођи! (ја те позивам)

(2) 'зашто нећеш / не желиш да дођеш? (у заказано вријеме и мјесто)'

(3) 'зашто/због чега/због којег разлога не долазиш? (уопште; тако дуго; више)'

Руски перфективни презент, који, за разлику од српског (јужнословенског, са изузетком словеначког), има обиљежја граматикализованог глаголског облика (футура СВ), може се семантички представити на сљедећи начин:

(18б) Почему ты не придещь? :

(1) ‘приходи!' (я тебя приглашаю) [ср. *'приди!']

(2) 'по какой причине ты не хочешь приходить (вообще) / прийти (в назначенное время и место)?

(3) 'по какой причине ты не приходишь? (вообще; так долго; больше)'

(4) 'по какой причине ты не придешь? (в назначенное время и место)' (sic!).

Наведена експликација показује да се употреба СВ не своди на просту замјену НСВ. Другим ријечима, СВ у овом случају не само да чува основно значење НСВ већ „обогаћује“ исказ додатним значењима, које није могуће изразити употребом $\mathrm{HCB}$, што значи да се овдје не ради о „равноправној“ супституцији (конкуренцији) двају супротстављених чланова бинарне видске опозиције. Илуструјмо то напоредним навођењем датих исказа у српском и руском језику:

(19a) Зашто не дођеш?

vs. Зашто не долазиш?

(19б) Почему тыл не придешь? vs. Почему ты не приходишь?

$[\mathrm{HCB}=(3)$ 'зашто/због чега/због којег разлога не долазиш?' (уопште; тако дуго; више) / (2) 'зашто/због чега/због којег разлога нећеш / не желиш да долазиш?' (уопште)]

$[\mathrm{HCB}=(3)$ 'по какой причине ть не приходишь?' (вообще; так долго; больше) / (2) 'по какой причине ты не хочешь приходить?' (вообще) / (1) ‘приходи!' (я тебя приглашаю) (?)]

На основу експликације, односно рашчлањивања на семантичке компоненте исказа са употребљеним презентом СВ, могли смо да примијетимо да наведена употреба презента СВ (што важи не само за српски и руски већ и за све остале словенске језике) садржи четири исте (заједничке) компоненте, тј. да се, поред формално изражених, али секундарних, узрочно-посљедичних односа (2) и (3), који се могу изразити и НСВ, на индиректан начин исказује и својеврсно апстрактно значење глаголске радње (које представља „унутрашњи“ синкретизам исказа)
О видско-временској синонимији и метафори у српском, руском и другим...

врло блиско „неправој“ (неактуелној) садашњости (3), те специфичан волунтативни однос, јер адресат 'не жели да дође’ (2), али и позив (1), као имплицитни прескриптивни перформатив (са обиљежјем 'очекујем'). Све ове компоненте указују на то да перфективни презент у датом случају нема временско значење. Његова употреба је овдје модална, иако је непосредно повезана с говорним тренутком, односно са актуелном садашњошћу. То такође значи да СВ (перфективни презент, односно футур СВ) у наведеним примјерима нема конкретно-процесуално значење. Другим ријечима, он има, условно речено, општефактичко, али нерезултативно значење, јер актуелна садашњост, која увијек подразумијева имперфективност глаголске радње, не „покрива“ његову овакву употребу, што истовремено значи да су вршење радње (о којој се овдје мисли и говори) и говорни тренутак раздвојени. Ту чињеницу сликовито одражава и тзв. „Миклошичево правило“ (Miklosich 1926: 274-275), према којем се на питање Што (сада, овдје) радии? не може одговорити перфективном формом (презентом СВ), већ само имперфективном (тј. презентом НСВ као граматикализованим изразом актуелне садашњости),

Компонента (4) у руском језику могла би се протумачити као временска употреба футура СВ са конкретно-фактичким значењем ('почему ты не придешь не будешь приходить'; срп. 'зашто нећеш доћи'), али само у случају, ако би неко лексичко средство или укупан контекст (ситуација) у ком се реализује дати исказ указивали на одређени (локализовани) тренутак (период) на плану будућег времена на који се односи употреба СВ (уп., нпр., Почему ты завтра не придешь?)

Треба такође додати да је употреба презента СВ с негацијом условљена како ситуационим тако и синтаксичким и лексичким контекстом. Тако, на примјер, ако бисмо у наведеним исказима прилог зашто (рус. почему) замијенили партикулом зар (рус. разве), којом се изражава како провјера истинитости информације до које је дошао адресант тако и чуђење које је она изазвала код њега, онда би се употребом СВ (као и супституцијом, односно транспозицијом НСВ) реализовало конкретно-фактичко значење и, самим тиме, стекли услови за локализацију глаголске радње на плану будућег времена (гдје у српском језику није могуће употребити презент СВ, већ само „прави“ футур). УП.:

(20а) (срп.) *3ар не дођеш (презент СВ)?

Зар не долазиш (презент НСВ)?

$\left(20 \mathrm{a}_{1}\right)$ (срп.) Зар нећеш доћи (футур СВ)?

Зар нећеш долазити (футур НСВ)?

(20б) (рус.) Разве ты не придешь (презент-футур СВ)?

Разве ты не приходишь (презент НСВ)?

Разве ты не будешь приходить (футур НСВ)?

2.1.4.2. Слична употреба СВ може се срести и у другим ситуацијама, прије свега у сјевернословенским језицима, о чему говоре и сљедећи примјери у руском, пољском, чешком и словачком језику:

Славистика XXIII/1 (2019) 
22

\author{
(21a) (рус.) Я этого не пойму (CB)
}

Я этого не понимаю (НСВ).

(21б) (пољ.) Ja tego nie rozumiem (CB).

Ja tego nie zrozumiem (HCB).

(21в) (чеш.) Já to nechápu (CB).

Já to nepochopim (HCB).

(21г) (словач.) Ja to nechápem (CB).

Ja to nepochopim (HCB).

$\mathrm{CB}$, за разлику од НСВ (који означава конкретно-процесуалну радњу у актуелној садашњости - ‘ ја то не схватам'), у овим примјерима има општефактичко нерезултативно и модално (потенцијално) значење, тј. значење немогућности вршења радње ('ја то не могу да схватим'), без обзира на то што се исказ реализује у говорном тренутку као неодвојивом дијелу актуелне садашњости. Адресант својим наративним исказом чија је радња СВ везана за говорни тренутак, односно за актуелно вријеме „посматрача“, указује на своје безуспјешне покушаје да реализује радњу, која на тај начин поприма (,,имплицитни“") конативни карактер. Другим ријечима, у датом случају на актуелну садашњост, односно на говорни тренутак односи се, како је то исправно уочио А. В. Бондарко (1971a: 221), „не процесс осуществления действия, а выражение невозможности его осуществления" “.

2.1.4.3. Употребу словенског СВ у условима у којима (према већ споменутом „Миклошичевом правилу“) функционише искључиво НСВ понекад омогућује и корелација специфичног прагматичког контекста исказа и лексичко-семантичких обиљежја основне глаголске радње. Такву синонимично назначену корелацију и употребу СВ могуће је реализовати у оквиру актуелне перформативне садашњости, односно у оквиру перформативних исказа, који се обично дефинишу као искази са глаголима verba dicendi у 1 . л. јд. индикативног презента НСB, чијим изговарањем адресант врши њима еквивалентну радњу (више о таквој могућности употребе СВ в., поред осталог, у Škrabec 1903, 1906 1912; Mazon 1914: 130-133; Koschmieder 1934: 107-110; Musić 1935; Vojvodić 1988; Žagar 1989: 128-176; Бондарко 1990: 32-39; Derganc 1993; 1996; 1998; Апресян 1995: 199-241; Војводић 1998б; Войводич 2010, 2015б; Dickey 2000 177-188; Вимер 2014; Славкова 2014). Међутим, дати тип употребе СВ немају сви перформативни гаголи, већ само мањи број њих, по правилу, само неки од оних који припадају групи глагола са проспективним (у најширем смислу футуралним) обиљежјима пропозиционалне валентности. Том перформативном способношћу одликују се, на примјер, руски глаголи попросить, (no)co-

${ }^{5}$ Уп. за дати тип употребе презента СВ термин А. Зализњака «презенс напрасного ожидания» (Зализняк 1993); уп. такође Rassudova 1984: 121; Маслов 2004: 80, 83; Петрухина 2008; Климонов 2011: 264-265.
О видско-временској синонимији и метафори у српском, руском и другим...

ветовать, поспорить, пожелать и сл., као и њихови еквиваленти у осталим сјевернословенским језицима. Уп. сљедеће примјере у руском и пољском, као и њихове модификације (,праве“, канонске перформативе са глаголима НСВ):

(22a) (рус.) Попрошу (СВ) вас минутку помолчать (Булгаков 1982) Проиу (НСВ) вас минутку помолчать.

(22б) (пољ.) Poproszę (CB), aby pani na chwilę przestała mówić (Bułhakow 1996). Proszę (HCB), aby pani na chwilę przestała mówić.

(23a) (рус.) Поспорю (СВ) с тобой, что он не придет на собрание. Спорю (НСВ) с тобой, что он не придет на собрание.

(23б) (пољ.) Założę się (CB) z tobą, że on nie przyjdzie na zebranie. Zaktadam się (HCB) z tobą, że on nie przyjdzie na zebranie.

Овај тип употребе $\mathrm{CB}$ сусреће се и у јужнословенским језицима, али са неким специфичностима, које их разликују од сјевернословенских језика. С једне стране, у словеначком језику се, као и у сјевернословенским језицима, такође користи презент СВ (који и у овом језику понекад, напоредо са граматикализованим футурским облицима, може да има футурско значење), али, сада - за разлику од њих - готово од свих перформативних глагола, како оних са проспективном тако и оних са ретроспективном семантиком, док се, с друге стране, у српском, бугарском и македонском ова (презентска) форма СВ не сусреће у перформативној употреби; њен најближи еквивалент у овим језицима је футур $\mathrm{CB}$, чија је употреба везана, као и у сјевернословенским језицима, за ограничени број перформативних глагола са проспективном семантиком. Уп. сљедеће примјере перформативне употребе СВ у словеначком језику, која није могућа у сјевернословенским језицима:

(24) Povabim (CB) vas, da pridete k nam na večerjo.

Vabim (HCB) vas, da pridete $\mathrm{k}$ nam na večerjo.

(25) Obljubim (CB) vam, da pridem. ${ }^{6}$

Obljubljam (HCB) vam, da pridem.

УП. такође српске еквиваленте наведених руских и пољских примјера (22a) $-(236)$ :

${ }^{6}$ Уп. дословни превод ова два посљедња примјера и на руски језик, у којем се презентом СВ изражава неперформативно, тј. „право“ футурско значење: *' приглаиу вас к нам на ужин', *'пообещаю' вам, что приду. Уп. такође превод на српски, гдје се у датом значењу не може употребити не само презент СВ већ ни футур СВ (као најчешћи екивалент руског, односно сјевернословенског, а понекад и словеначког презента СВ): *'позваћу вас да дођете код нас на вечеру'; *'обећаћу вам да ћу доћи'

Славистика XXIII/1 (2019) 
(26) Замолићу (футур СВ) (уп. *замолим (презент СВ)) вас да умукнете на тренутак (наш превод - Д. В.)

Молићу (футур НСВ) вас да умукнете на тренутак.

Молим (презент НСВ) вас да умукнете на тренутак (Булгаков 1985).

(27) $O($ (п)кладићу се (футур СВ) (уп. *опкладим се (презент СВ)) с тобом да он неће доћи на састанак.

Кладићу се (футур НСВ) с тобом да он неће доћи на састанак.

Кладим се (презент НСВ) с тобом да он неће доћи на састанак.

Уп. сличну употребу перформатива (изражених футуром СВ) и у бугарском и македонском језику:

(28) Ще ви помоля (футур СВ) (уп. *помоля (презент СВ) ви) да кажете кои от двата варианта ви допада повече (Фото Форум 2015)

Ще ви моля (футур НСВ) да кажете кои от двата варианта ви допада повече. Моля (презент НСВ) ви да кажете кои от двата варианта ви допада повече.

(29) Јac ќe Ве очекувам. Ḱe ве замолам (футур СВ) (уп. *замолам (презент СВ) ве) да дојдете (Џекова, Захов 2012).

Јас ќе Ве очекувам. Ќе ве молам (футур НСВ) да дојдете.

Јас ќе Ве очекувам. Молам (презент НСВ) ве да дојдете.

Напоменимо да је конкуренција у наведеним српским (као и у бугарским и македонским) примјерима (еквивалентима) само видска, док је у сјевернословенским језицима видско-временска. ${ }^{7}$

На основу претходних примјера можемо закључити да се за означавање перформативне глаголске радње користе, по правилу, само они облици и конструкције којима је својствена проспективна (футурална) валентност (с обзиром на темпоралнни карактер садржаја-предиката у пропозицији-диктуму). Према томе, облици прошлога времена, за које је карактеристична ретроспективност, не би требало да се реализују у датом (перформативном) контексту. Међутим, у појединим словенским језицима (посебно у српском) повремено се могу срести и случајеви употребе претериталних облика у илокуцији пер-

${ }^{7}$ Видско-временска конкуренција могућа је и у српском језику, али само ако се перформативни презент НСB потпуно замијени футурским обликом НCB, јер у српском у датим случајевима и футур СВ и футур НСВ могу да се употребе перформативно; уп.: Замолић / молићу ('молим <вас>') вас да умукнете на тренутак; $O($ (n)кладићу се / кладићу се с тобом ('кладим се $<$ с тобом>') да он неће доћи на састанак. Слично је и у бугарском и македонском језику; уп.: (буг.) Ще ви помоля / ще ви моля ('моля <ви>') да кажете кои от двата варианта ви допада повече; (мак.) Ḱe ве замолам / ќe ве молам ('молам <ве>') да дојдете.

Славистика XXIII/1 (2019)
О видско-временској синонимији и метафори у српском, руском и другим..

формативног исказа, тј. у оквиру актуелне (перформативне) садашњости, на које бисмо овом приликом жељели да се додатно осврнемо (макар и у кратким цртама), нарочито стога што се на први поглед чини да је ријеч о специфичној врсти видског „парадокса“, тј. да се и таквом употребом „нарушава“ наведено „Миклошичево правило“. Наиме, у разговорном српском језику понекад се може срести перформативна употреба партиципа прошлог времена СВ, која је, по свему судећи, „изворно“ територијално ограничена (према нашим апроксимативним процјенама - прије свега на новоштокавски ареал лоциран на ширем подручју сјеверозападне Србије). ${ }^{8}$ Напоменимо узгред да смо дати тиг перформативног исказа регистровали свега два пута - у Београду и Врбасу (в. Войводич 2000а: 120)., гдје су и забиљежена сљедећа два примјера:

(30) Умољени сте да припремите реферат за штампу ('умољавам вас'; 'молим вас');

(31) Замољен/позван си да дођеш до нас ('молим те'/ 'позивам те').

Додајмо да се претериталне форме (укључујући и пасивне партиципе прошлог времена СВ) у прескриптивној употреби у словенским језицима (које се могу срести у разговорном језику, а релативно однедавно - у савременим условима информационих технологија - и (нарочито) на Интернету, и то најчешће у оквиру различитих форума и друштвених мрежа, гдје се као комуникативна форма обично користе мишљења-коментари), не могу сматрати „пуноправним“ перформативима јер немају перформативно-резултативно значење с обзиром на то да представљају само метафорички (транспоновани, аксиолошко-експресивни) израз подстицања адресата на радњу вршећи притом функцију својеврсног ритуализованог говорног чина (без формално означеног адресанта) са појачаним ефектом дјеловања на адресата; уп. нпр.:

(32) (срп.): Позвани (СВ) сте на рођендан! [‘Я Вас позивам (да дођете) на рођендан']. ${ }^{9}$

Уп. такође употребу партиципа прошлог времена НСВ који у датом контексту нема перформативно (већ само претеритално) значење:

(33а) * Звани [позивани $]$ (НСВ) сте на рођендан! ${ }^{10}$

${ }^{8}$ На такву могућност посебно је указала и акад. Милка Ивић у дискусији поводом нашег реферата (посвећеног перформативима) прочитаног 1996. год. на XXVI међународном научном састанку слависта у Вукове дане у Београду.

${ }^{9}$ Подробније о перформативним исказима датога типа (нарочито на друштвеним мрежама, гдје се овакви перфектни перформативи интензивно шире), у којима се информација жама, гдје се овакви перфектни перформативи интензивно шире), у којима се информација о радњи са формалним обиљежјем перфектности даје са ослонцем на њено посматрање

${ }^{10}$ Дато претеритално значење може се изразити и пасивним обликом плусквамперфекта (што значи да се партиципска радња у овом случају може и дезакатуелизовати додатним контекстом); уп.: (33б) Звани (НСB) / позвани (СВ) сте на рођендан [али нисте дошли / па сте дошли]; (33в) Били сте звани (НСВ) / позвани (CB) на рођендан [али нисте дошли (,Јер cy многи звани, али је мало изабраних“- Мт 22: 14)].

Славистика XXIII/1 (2019) 
26

Дојчил П. Војводић

Уп. и сличну (перформативну) употребу безличних (такође без формално означеног адресанта) непрескриптивних ритуализованих форми (у рус. -3 . л. мн. през. НСВ; у пољ. и срп. - пас. парт. прошли СВ)

(34а) (рус.) Тебя прощают ['прощаю тебя/тебе' (уп. 'тебе прощается'; срп. 'опрашта ти се')]. Не будут больше подавать платок (Булгаков 1982);

(34б) (пољ.) Wybaczono ci ['wybaczam ci']. Nie będą ci już więcej przynosić chustki (Bułhakow 1996);

(34в) (срп.) Опроштено ти је ['опраштам ти']. Марамицу ти више неће давати (Булгаков 1985). ${ }^{11}$

Може се претпоставити да је један од разлога могућности употребе датих форми у перформативној улози вјероватно у томе што оне (за разлику од „неперфектних" - претериталних и футуралних - пасивних форми, односно исказа типа Били сте/бићете умољени да дођете до нас) „покривају“ (повезују) два временска плана - прошло и садашње вријеме, односно у њиховој „темпорално инклузивности“, која - као обиљежје категорије перфектности - актуелизује исказ у говорном тренутку, захваљујући чему долази и до „перформативног ефекта“ (Војводић 2018: 94-95). ${ }^{12}$

\section{3. Видско-временска транспозиција (метафора) и конкуренција}

3.1. Praesens historicum. Изражавање прошле радње презентским обликом (историјским презентом) представља пренесено значење, односно својеврсну метафору вида и времена (или само времена), гдје се значење овог глаголског облика формално разилази са темпоралношћу контекста (Бондарко 1958а,

${ }^{11}$ Сличну могућност употребе пасивног партиципа перфекта (као индиректног експлицитног перформатива) имају и други, несловенски језици (с том разликом што се тамо „не препознаје“ СВ од НСВ); уп. фр. превод (такође са пасивним партиципом перфекта) наведеног примјера: Tu es pardonnée. On ne t'apportera plus le mouchoir (Boulgakov 1975).

${ }^{12}$ Треба нагласити да се „Миклошичево правил““ и овдје (ипак) не нарушава, јер се перформативним исказом, без обзира на то да ли је ријеч о имперфективном или перфективном презенту, или пак о неком другом перформативном средству (укључујући и партицип перфекта СВ), не означава (не описује) радња која протиче у тренутку говора (тј. не означава се „права”, актуелна садашњост), него само чин (молба, позив, савјет, заклетва, захтјев, наредба, опклада и сл.) онога који говори, тј. чин који нема конкретно-процесуално (актуелно-дуративно) значење, већ - супротно томе - има резултативно значење (уп. Апресян 1995: 239), а који се остварује изговором одређене ријечи (именовањем) изједначеним са наведеним илокутивним актима (односно изговором и њихове допуне као дијела укупног перформативног исказа).

Перформативном употребом, тј. примјеном перформативне формуле перфективност се на одређен начин потире. Другим ријечима, морфолошке видске особине глаголских облика се неутрализују, јер да није тако, овако употребљен презентски облик СВ у горенаведним примјерима означавао би будуће вријеме. Исто тако, и футур I (CB и НCB), као и пасивни паритицип перфекта СВ у српском језику губи своје како временско тако и видско одређење (в. Войводич 2015б: 32; Војводић 2018: 340-341).

О видско-временској синонимији и метафори у српском, руском и другим..

1971a: 129; ср также Mazon 1914: 149-159; Panzer 1963; Forsyt 1970: 179-183; Rathmayr 1976; Потебня 1977: 124-145; Прокопович 1982: 269-277; Војводић 1989; Войводич 1998a: 122-124; Vojvodič 2018; Фичи Джусти 1996: 315-317; Меркулова 1997; Ремчукова 1997; Dickey 2000: 126-154; Тошович 2006: 141154; Попович 2015; Петрухина 2019: 33-35). Напоредна употреба, односно међусобна замјена презентских облика СВ и НСВ са очувањем исте видске вриједности (једнократне прошле радње $\mathrm{CB}$ ) слободнија је у руском језику; у српском се на овом мјесту најчешће користи презент $\mathrm{CB}$, који се не може тако лако замијенити презентом $\mathrm{HCB}$, а да се при том не измијени и видска вриједност коју има глаголска радња СВ. Могућност такве супституције доводи до конкуренције СВ и НСВ.

На основу проведене анализе српско-руског корпуса могу се издвојити четири значења историјског (транспонованог, метафоричког) презента: (1) значење прошле уобичајене радње, (2) значење прошле радње која се понављала и смјењивала, (3) аористно значење и (4) сценско значење.

3.1.1. Значење прошле уобичајене радње. Дато значење перфективни презент добија од контекста - лексичких показатеља (најчешће прилога) и форме прошлог времена. УП.:

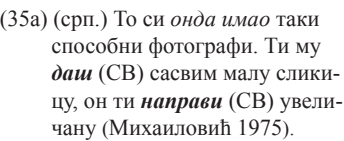

(35а) (срп.) То си онда имао таки способни фотографи. Ти му даш (СВ) сасвим малу сликицу, он ти направи $(\mathrm{CB})$ увеличану (Михаиловић 1975).

(35б) (рус.) Фотографы тогда дошлые были. Дашь (СВ) ему малюсенькую карточку, а он те изделает (СВ) большую (Михаилович 1978).

У примјерима (35а) и (35б) прилози (онда - тогда) и облици прошлог времена (имао - были), претходећи употреби перфективног презента, тј. радњама које се уобичајено извршавају (заправо, устаљено понављају), стварају простор (услов) за употребу перфективног презента (даи, направи - дашь, изделает), односно смјештају овај глаголски облик у прошло вријеме.

3.1.2. Значење прошле радње која се понављала и смјењивала. У датом случају понавља се једна те иста радња или неколико радњи (изражених перфективним презентом) које се међусобно смјењују. Другим ријечима, овдје се не понављају читаве ситуације (као у претходном случају), већ се понављају (и смјењују једне друге) радње у оквиру једне одређене, конкретне ситуације, о којој адресант има сликовиту предоџбу. Уп.:

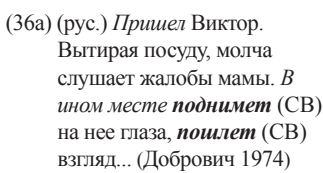

(36б) (срп.) Дошао је Виктор Бришући посуђе, шутке слуша мајчине жалбе. Понекад подигне (СВ) на њу очи, погледа (CB) je... (Dobrovic 1977) 
Пришел Виктор. Вытирая посуду, молча слушает жалобы мамы. В ином месте поднимает (НСB) на нее глаза, посылает (НСВ) взгляд...

У наведеним примјерима контекст помоћу форме прошлог времена (npuшел - дошао је) одређује временски план, а помоћу лексичког показатеља квантификатора ирегуларне епизодичне итеративности (в ином месте 'иногда' - понекад) указује на то да се радње изражене перфективним презентом (поднимет, пошлет - подигне, погледа) понављају и међусобно смјењују, истовремено означавајући свој референцијални статус.

Уп. употребу облика прошлог времена у оба поређена језика:

$$
\begin{aligned}
& \text { (37a) (рус.)... В ином месте } \\
& \text { поднимал (НСВ) на нее глаза, } \\
& \text { посылал (НСВ) взгляд... }
\end{aligned}
$$

$$
\begin{aligned}
& \text {... В ином месте * поднял }(\mathrm{CB}) \\
& \text { на нее глаза, * послал }(\mathrm{CB}) \\
& \text { взгляд. }
\end{aligned}
$$

(37б) (срп.) Понекад је подизао (НСВ) на њу очи, погледавао (HCB) je.

* Понекад je *nодигаo (CB) на њу очи, *погледао (СВ) је.
Сличну неадекватну модификацију видске супституције у поређеним језицима могуће је, барем у одређеној мјери, „превладати“ употребом облика погодбеног начина (кондиционала) у српском језику (в., поред осталог, Kalsbeek, Lučić 2008); уп.: (38а) (срп.) Понекад би подизао (НСВ) на њу очи, погледавао (би) (HCB) je.

(38б) (срп.) Понекад би подигао

(CB) je.
(СВ) на њу очи, погледао (би)

У сљедећем примјеру једна те иста радња се понавља у оквиру једне одређене ситуације. Уп.:

(39а) (срп.) И све тако редом, алатка по алатка, а на крају сваке реченице записани предмет тупо јекне [СВ] (...) (Андрић 1963).

(39б) (рус.) И так по порядку, инструмент за инструментом, и в конце каждой фразы записанный предмет глухо брякает [НСВ] (...) (Андрич 1978).

(39в) (пољ.) Z końcem każdego zdania zapisany przedmiot spada [НCB] z głuchym szczękiem (...) (Andrić 1977).
О видско-временској синонимији и метафори у српском, руском и другии..

Понављање радње овдје је условљено узрочно-посљедичном везом јер „предмет јекне [рус. брякает; пољ. spada]“ послије „сваке [изговорене] реченице“. У преводним еквивалентима на руски и пољски језик умјесто перфективног презента (брякнет, spadnie) употребљен је имперфективни презент (брякает, spada), што у овим језицима не доводи до измјене смисла изворне реченице (уп. такође горенаведни примјер (36а))

Треба истаћи да употреба перфективног презента у датом значењу доводи до одрећених измјена (пауза или прекида) темпа излагања. Било да је радња уобичајена (3.1.1.), било да се понавља и смјењује другом радњом (3.1.2.), она у овим двјема употребама перфективног презента има итеративно значење. Другим ријечима, СВ овдје реализује конкретно-типично значење (ср. Бондарко 1971а: 22).

3.1.3. Аористно значење. У литератури се појам видске конкуренције често повезује с појмом видске неутрализаиије (уп., нпр., Kř́žková 1965; Бондарко 1971a:226-234;Петрухина 1978; Семиколенова 2003). Ријеч је о оним случајевима видског контекста када НСВ покрива не само своју видску вриједност већ и видску вриједност СВ, односно када презент СВ, због колизије са његовим футурским значењем (у руском и другим сјевернословенским језицима), није могуће употребити (најчешће, на плану прошлог времена) за исказивање цјеловитих једнократних радњи које се не понављају. Такви примјери употребе НСВ којом се „неутралише“ бинарна видска опозиција карактеристични су, прије свега, за историјски и сценски презент, чиме се посебно одликује руски језик. У српском језику у датом случају перфективни презент могуће је замијенити аористом и обрнуто, а да се смисао реченице-исказа не промијени (уп. Стојићевић 1951: 34 73; Ивић 1953-1954: 229-262; уп. такође Стевановић 1969: 583-587; Бондарко 1971б; Војводић 1989: 90-92; Radovanović 1990: 168-174; Танасић 1996: 152 155; Пипер, Клајн 2013: 396-397). Другим ријечима, перфективни презент у овом значењу употребљава се за означавање појединачних, једнократних и конкретних рањи које се не понављају (конкретно-фактичко значење), односно које су биле остварене и завршене у прошлости. ${ }^{13}$

УП. сљедеће примјере исказивања једнократне прошле (,аористне“) радње у српском језику (гдје видска конкуренција није могућа, али јесте конкуренција претериталних глаголских облика СВ) и руском (гдје је избор вида и времена, односно конкуренција могућа), као и њихове међусобне еквиваленте: (40а) (срп.) Она устукне и сакрије [аорист: 'устукну', 'сакри'/ перфекат: 'устукнула је', 'сакрила је' - Д.В.] нагло руке у наборе хаљине (Novak 1961).

У примјеру (40б) у руском језику употребљена је форма прошлог времена, која је најчешћи еквивалент српског перфективног презента у датој употреби.

${ }^{13}$ Перфективни презент овдје нема своје сопствено темпоралнио обиљежје (уп. Стојићевић 1951: 34-73; Грубор 1953: 147-148); своју темпоралност он добија од контекста, тј. од имперфективног презента, који у том истом контексту замјењује форму прошлог времена (уп. Бондарко 1958б: 150; Musié 1902: 479 и д.; Пипер 1985: 54-55). (40б) (рус.) Она вздрогнула и быстро спрятала ['вздрагивает', 'прячет' - Д.В.] руки в складках юбки (Новак 1978). 
$\underline{30}$

Дојчил П. Војводић

Уп. сљедећи примјер, гдје је у руском преводу употребљен имперфективни презент:

(41а) (срп.) Магле се расене, подвију [аорист: 'расенише се', 'подвише се' / перфекат: 'расениле су се', 'подвиле су се' - Д.В.] у поткровља

и ниске тремове (Исаковић 1964).

Употребом имперфективног презента у руском језику у примјеру (41б) реализује се „двострука“ транспозиција: садашње вријеме - у прошло вријеме и $\mathrm{HCB}$ - у СВ. Другим ријечима, пред нама је потпуна („обавезна“) видска неутрализација, гдје је НСВ у потпуности преузео на себе функцију СВ, чувајући истовремено своју сопствену специфичност (Бондарко 1971a: 226; ср. Koschmieder 1934: 97-102; Dickey 2000: 143-145; Маслов 2004: 110; Петрухина 2009: 74).

Додајмо да се перфективни презент у руском језику у наведеном значењу употребљава само у конструкцији са партикулом как од глагола једноактне и ингресивне врсте радње, при чему се као обавезни пратећи елемент користи и посебна - појачана (узвична) - интонација (уп. Исаченко 1960: 459; Виноградов 1972: 454-456; Бондарко 1971a: 163-164; Гловинская 2001: 198-199; Маслов 2004: 109); уп. превод српског аориста на руски језик:

(42а) (срп.) Кад, негде после подне, може бит око три, мен одједанпут нешто секну преко стомака (Михаиловић 1975).

У примјеру (42б) конструкцијом как полоснет изражава се неочекивана и интензивна радња у прошлости, а лексички показатель вдруг указује на њен изненадни наступ. ${ }^{14}$

3.1.4. Сценско значење. До појаве видске неутрализације може такође доћи и у тзв. сценском презенту. У руском језику, за разлику од српског, у ремаркама (дидаскалијама) драмских дјела, у којима се управо и испољава дато значење, не употребљава се перфективни, већ имперфективни презент, или пак - рјеђе - форма прошлог времена. Уп. сљедећи примјер у српском/српскохрватском (у којем је замјена СВ и НСВ могућа) са његовим еквивалентом у руском језику (у којем замјена вида није могућа):

${ }^{14}$ Употреба перфективног презента у датој конструкцији (као и употреба српског перефективног презента или аориста у одговарајућем контексту) увијек доводи до резултативности радње и до измјене ритма излагања, што нарочито долази до изражаја при употреби моменталних глагола (какви су и наведени), с обзиром на то да «они обозначают факт скачкообразного, "точечного" перехода к новому качеству не только в формах совершенного, но и в формах несовершенного вида» (Апресян 1995: 228).
О видско-временској синонимији и метафори у српском, руском и другим... (43а) (срп.) Сестра Магдалена: Збогом, велечасни. (Изађе [cp. излази] лијево оним истим тихим корацима оборене главе) (Маринковић 1966).

(44а) (срп.) Дон Зане: (Остаје насред собе са смијешком на лицу, затим се полако окрене [ср. окреће] и уђе [ср. улази] у библиотеку) (Маринковић 1966).
(436) (рус.) Сестра Магдалина: С богом, преподобный отец. (Уходит [ср. *уйдет] влево теми же тихими шагами, печально опустив голову.) (Маринкович 1974).

(44б) (рус.) Отец Зане: (Стоит посреди комнаты с улыбкой на лице, затем медленно поворачивается [ср. *повернется] и идет [ср. *войдет] в библиотеку) (Маринкович 1974).
Овдје транспозицију времена (садашње вријеме $\rightarrow$ прошло вријеме) у руском језику обавезно прати и транспозиција вида $(\mathrm{HCB} \rightarrow \mathrm{CB})$, усљед чега се као и у случају „аористног“ значења историјског презента, реализује потпуна (,обавезна“) видска неутрализација (подробније о датој појави у руском језику в. Бондарко 1962; 1971a: 226-234; уп. такође Israeli 2018, гдје је размотрена специфична употреба глагола кретања у значењу сценског презента у руском језику; о контрастивном проучавању овог питања у руском и чешком в., поред осталог, Bareš 1956; Křížková 1965; Петрухина 1976). Другим ријечима, имперфективним презентом исказују се глаголске радње и СВ и НСВ. У српском језику имамо другачију временску транспозицију, коју, по правилу, прати иста видска вриједност (усљед чега видска неутрализација није могућа, или је крајње ограничена), што значи да се имперфективним презентом исказују радње НСВ, а перфективним - радње СВ захваљујући чему се у датим контекстуалним условима бинарна видска опозиција и чува (уп., нпр., Kravar 1964: 40; Војводић 1989; уп. такође за ситуацију у словеначком језику Derganc 2003: 72-73). СВ и у овој (сценској) употреби у српском језику има конкретно-фактичко значење, на што додатно упућује и могућност употребе на овом мјесту аориста.

3.1.5. Иако је увријежено мишљење да је за српски језик карактеристична досљедна видска супротстављеност, тј. да нема видске неутрализације, она је, ипак, понекад могућа, макар и непотпуна и не тако честа (иако, по правилу, у разговорном језику), на што је међу првима указао руски аспектолог А. В. Бондрако (19586: 147-148), који је на материјалу (само) неколико књижевних дјела српских писаца открио одређени степен дате појаве. Као илустрацију навешћемо један релативно повезан дио текста из романа Р. Петровића (гдје је и А. В. Бондарко такође нашао низ примјера видске неутралиације):

(45) Унутра гори свећа. Седам ['сео сам'/ 'седох' / 'седнем'] за сто испод свеће и покушавам да читам Живот Челиниев. (...) Долази [‘дошао је' /‘дође'] један пуни, задовољни старац. (...) Ујутру ме буди ['пробудила' ‘пробуди'] грдна ларма петлова. Искачем ['искочио сам' / ‘искочих' / ‘искочим'] из постеље кијајући, умивам се ['умио сам се' / 'умих се' / 'умијем се'] и силазим ['сишао сам' / 'сиђох' / 'сиђем'] на улицу. (...) Ја сам у чамцу између Острва и Ескалоне (Петровић 1996). 
Ради боље прегледности издвојимо глаголе употребљене у имперфективном презенту који у наведеној групи реченица „неутрализује“ (видски „покрива“) глаголске облике СВ (перфект, аорист и перфективни презент):

Седам (презент НСВ) = 'сео сам’ (перфект СВ); 'седох' (аорист СВ); 'седнем' (презент СВ)

Долази (презент НСВ) = ‘дошао је' (перфект СВ); ‘дође' (аорист СВ / презент СB)

буди (презент НСВ) = 'пробудила' (перфект СВ); ‘пробуди' (аорист СВ / презент СB)

Искачем (презент НСВ) = 'искочио сам' (перфект СВ); 'искочих' (аорист $\mathrm{CB})$; 'искочим' (презент СB)

умивам се (презент НСВ) = 'умио сам се' (перфект СВ); 'умих се' (аорист $\mathrm{CB})$; 'умијем се' (презент СВ)

силазим (презент НСВ) = 'сишао сам' (перфект СВ); 'сиђох' (аорист СВ); 'сиђем' (презент СВ)

С обзиром на то да је у српском језику видска неутрализација слабо заступљена, за наведене примјере историјског презента можемо рећи да они одражавају, прије свега, индивидуални стил писца, који широм употребом (транспозицијом) једног глаголског облика НСВ (имперфективног презента) успијева да појача степен експресивности свог наративног израза, те да се дата појава у српском језику - усљед већих могућности избора других (синонимичних имперфективном презенту) средстава за изражавање прошлих радњи СВ - може сматрати само факултативном (Маслов 2004: 109; уп. Савић 1985; Поповић 2015: 205).

3.2. Praesens pro futuro. У српском и другим словенским језицима налазимо веома раширену употребу имперфективнога презента у функцији футура (praesens pro futuro). Треба истаћи да пренесено значење овога облика, по правилу, подразумијева двоструку транспозицију - временску и видску. Другим ријечима, транспонује се садашње вријеме у будуће, а НСВ - у СВ. Број глагола који подлијежу оваквој транспозицији прилично је ограничен. То су прије свега глаголи кретања (в., поред осталог, Пипер 1985, Војводић 1996) са значењем почетка вршења радње (инхоативне или ингресивне радње), односно глаголи који се (као потенцијална особина субјекта) најчешће вежу за категорију аниматности (тј. за категорију „живога“, односно категорију бића). Датом транспозицијом изражавају се, прије свега, једнократне и конкретне (временски локализоване) футурске радње. Уп. употребу презентског облика у истом контексту - из тзв. „објективног“ корпуса (превода са француског језика) ${ }^{15}$ - у сва три поређена језика:

15 Такву употребу презента познају, наравно, и други (несловенски) језици. Уп. исти примјер на француском језику (овдје оригиналу): (46г) Je m'en vais, ça me dégoûte (Zola 1978).
О видско-временској синонимији и метафори у српском, руском и другим.

(46а) (срп.) Идем, гади ми се на све (Зола 1974);

(46б) (рус.) Я ухожу, очень уж противно (Золя 1988);

(46в) (пољ.) Idę do domu, niech to wszystko diabli wezmą (Zola 1987).

Транспоновани презент чест је не само у изјавним већ и у упитним реченицама. УП. руски оригинал и његове преводе на пољски и српски језик, у којима је употребљен презент НСВ са значењем будућег времена СВ, односно паралелне видско-временске модификације са футуром СВ (који се у руском и пољском језику, као и у осталим сјевернословенским (источно- и западнословенским) језицима, формално подудара са презентом СB): (47a) (рус.) - Мы едем? Мы ведь правда едем? - добивается он в недоумении: почему они не отвечают? (Панова 1976)

(47б) (пољ.) - Jedziemy? Prawda, że jedziemy? / dopytuje się coraz bardziej zdumiony: dlaczego mu nie odpowiadają? (Panowa 1986)

(47в) (срп.) - Одлазимо ли? Ми заиста одлазимо, зар не? - упорно запиткује он у недоумици: зашто му не одговоре? (наш перевод Д. В.)
- Мы поедем? Мы ведь правда поедем? - добивается он в недоумении: почему они не отвечают?

- Pojedziemy? Prawda, że pojedziemy? - dopytuje się coraz bardziej zdumiony: dlaczego mu nie odpowiadają?

- Хоћемо ли отићи? Ми ћемо заиста отићи, зар не? - упорно запиткује он у недоумици: зашто му не одговоре?
Упитни прилози у оваквим случајевима могу представљати неодређене квантификаторе који су подударни са замјеничко-прилошким (просторним, временским, начинским и др.) локализаторима. Глаголи кретања најчеће се везују управо за упитно-просторне прилоге са обиљежјима адлативности, односно онда када су говорном лицу локализатор и намјера субјекта непознати (уп. Пипер 1978; 1988: 116-131). УП., поред наведених примјера, и сљедећи дијалог на руском, односно пољском и српском језику:

(48a) (рус.) Потом увидел, что она уже одета, и спросил с тревогой: - Ты уходишь? Куда ты уходишь? (Симонов 1977)

(48б) (пољ.) Zobaczył, że jest już ubrana i spytał z niepokojem: - Wychodzisz? Dokąd idziesz? (Simonov 1984)

(48в) (срп.) Затим виде да се она већ обукла, па је узнемирено запита: - Ти одлазиш? Куда ћеш? (Симонов 1962) 
34

Дојчил П. Војводић

У тренутку говора оваква радња је већ „плански“ замишљена, на одређен начин програмирана (praesens propheticum). Другим ријечима, она и прије своје материјалне реализације већ постоји у свијести говорног лица (Ермоленко 1987 62; уп. Mazon 1914: 125-127; Бондарко 1971a: 154; Гловинская 2001: 155-168). У овим примјерима можемо примијетити да глаголску радњу НСВ исказану презентом по правилу прати једна скривена модална нијанса - намјера субјекта. Наведени случајеви говоре о „блиској“ будућој радњи. Међутим, додавањем одговарајућих лексичких показатеља (односно контекста), као што су замјеничке ријечи (а прије свега временски прилози-локализатори типа данас, вечерас, сутра и сл.), које су комплементарне са глаголским облицима, оваква футуралност може се препознати као „даља“ будућа радња (уп. Пипер 1985: 54 и д.). Што је таква радња временски удаљенија од говорног тренутка (на што указују наведени локализатори), експресивност презентских облика је јача. Ови и њима слични локализатори могу имати мањи или већи степен временске референцијалности, коју остварују на различите начине (уп. Пипер 1988: 45-46). УП. српски оригинал и модификацију (примјер 49a) са њиховим преводом на руски језик (примјер 49б), у којима је, као и у примјерима (46а) - (48в), такође употребљен презент НСВ са значењем будућег времена СВ: (49а) (срп.) Другови! Ми вечерас напуштамо Јастребац. ( Ћосић 1966).

Другови! Ми ћемо вечерас напустити Јастребац... (49б) (рус.) Товарищи! Сегодня вечером мы оставляем Ястребац (Чосич 1956) Товарищи! Сегодня вечером мы оставим Ястребац.
УП. такође сљедећи примјер у српском језику (у којем је употреба футура НСВ помало „неприродна“) и његове еквиваленте у руском и пољском (гдје је употреба футура НСB, чини се, „природна“), као и у словачком језику (гдје је та употреба, као и у српском, донекле „неприродна“):

(50a) XVII међународни конгрес слависта одржава се (одржаваће се <!>) 2023. године у Паризу.

XVII међународни конгрес слависта одржаће се 2023. године у Паризу.

(50б) XVII Международный конгресс славистов проходит (будет проходить) 2023 года в Париже.

XVII Международный конгресс славистов пройдет 2023 года в Париже. (50в) XVII międzynarodowy kongres slawistów odbywa się (będzie się odbywać) w 2023 roku w Paryżu.

XVII międzynarodowy kongres slawistów odbędzie się w 2023 roku w Paryżu. (50г) XVII. medzinárodný zjazd slavistov sa uskutočňuje (sa bude uskutočňovat) v 2023 roku v Paríži.

XVII. medzinárodný zjazd slavistov sa uskutoční v 2023 roku v Pariži.
О видско-временској синонимији и метафори у српском, руском и другим..

У наведеним примјерима узајамне замјене футурски и транспоновани презентски облици НСВ могу да представљају опозициони члан у односу на футурски облик $\mathrm{CB}$, посебно у руском и пољском језику.

УП. превод примјера (50a) - (50г) и на словеначки језик, чији се видско-временски еквиваленти (како СВ тако и НСВ), за разлику од осталих словенских језика, у датом контексту изражавају само облицима НCB:

(50) XVII mednarodni kongres slavistov poteka / bo potekal leta 2023 v Parizu.

*XVII mednarodni kongres slavistov poteče / bo potekel leta 2023 v Parizu.

Примјећујемо да употреба презентско-футурских облика од глагола poteči (тј. од перфективног видског пара имперфективног глагола potekati) у датом контексту у овом језику, за разлику од горенаведених примјера са истим контекстом у другим словенским језицима, мијења смисао исказа. С обзиром на испољену видску ограниченост, и овдје можемо говорити о неутрализацији СВ.

\section{4. Умјесто закључка.}

На основу свега досад изложеног, а посебно на основу овдје анализираних примјера, запажамо, што треба и истаћи, да у свим словенским језицима НСВ чешће замјењује СВ, него обрнуто, што говори о томе да су његове функционалне границе шире од оних које има њему супротстављени СВ. На то посебно указује и његова специфична улога у неутрализацијама видске опозиције (посебено карактеристичним за руски језик) повезаним са ширењем семантике и повећањем броја функција НCB на рачун CB, гдје се видска вриједност $\mathrm{CB}$ врло често своди на минималну или чак, можемо то условно тако да назовемо, „нулту“ разину испољавања. Треба додати да је могућност узајамне замјене СВ и НСВ релативно ограничена у свим словенским језицима, у првом реду због утицаја контекста у којем се међусобно супротстављене категорије употребљавају. Поред тога, у сјевернословенским језицима (нарочито у руском), као и у словеначком језику, запажа се шира и донекле слободнија примјена такве (у оквирима једног те истог контекста) супституције (са очувањем исте видске вриједности) у односу на исту у јужнословенским језицима (укључујући и српски, на грађи којега се ово питање такође детаљније разматра). На крају, умјесто закључка, додајмо само још и то да у свим наведеним типовима видске супротстављености (као и несупротстављености) значајну улогу увијек има како лексичко значење глаголаิ и актуелизација њихових видско-временских облика (која је непосредно повезана са комуникативном усмјереношћу исказа) тако и контекст - било лексички, синтаксики или ситуациони - у којем се они употребљавају. Треба такође нагласити да видска значења СВ и НСВ у условима синтаксичке (контекстуалне) супституције нису потпуно синонимична будући да се семантика НСВ усљед „унутрашње“ компоненте „процесуалности“ не подудара у потпуности са семантиком CB, која се одликује једнократношћу радње. Дакле, овдје - када је ријеч о синтаксичком избору вида - можемо говорити о семантичком (стилском) „помјерању“ у односу на „полазно“ видско значење (вредност). Иако се видска конкуренција, односно супституција у сло- 
венским језицима може везати за било који временски план, односно глаголски облик, она се, ипак, најчешће везује за индикативне облике, гдје посебно мјесто и улогу имају презентски облици СВ и $\mathrm{HCB}$, што је показала и претходна анализа различитих типова контекста.

\section{Цитирана литература}

Аксаков, Константин. С. О русских глаголах. Москва: Типография Л. Степановой, 1855 Апресян, Юрий Д. Избранные труды. Т. ІІ: Интегральное описание языка и системная лексикография. Москва: Школа «Языки русской культуры», 1995.

Белић, Александар. Историја српскохрватског језика. Књ. II, св. 2: Речи са коњугацијом. Београд: Научна књига, 1973. [Белић Александар. Изабрана дела, том IV: Историја српског језика: Фонетика. Речи са деклинацијом. Речи са конјугацијом. Београд: Завод за уџбенике и наставна средства, 1999].

Бондарко, А. В. Настоящее историческое глаголов несовершенного и совершенного видов в славянских языках. АКД. Ленинград: ЛГУ, 1958а.

Бондарко, Александр В. «Настоящее историческое глаголов несовершенного и совершенного видов в современном литературном сербохорватском языке». Уч. записки ЛГУ. Сер. филол. наук 44/250, 1958б: 141-157.

Бондарко, Александр В. «Опыт общей характеристики видового противопоставления русского глагола». Ученые записки Института славяноведения АН СССР XXIII, 1962: 179-203.

Бондарко, Александр В. Вид и время русского глагола (значение и употребление). Ленинград: Просвещение, 1971а.

Бондарко, Александр В. «О взаимоотношениях форм аориста и настоящего совершенного в старых белорусских, чешских и польских памятниках». [В:] Е. В. Чешко (отв. ред.). Исследования по славянскому языкознанию. Сб. в честь профессора С. Б. Бернштейна. Москва: Наука, 1971б, 28-32.

Бондарко Александр В. (отв. ред.). Теория функциональной грамматики: Темпоральность. Модальность. Ленинград: Наука, 1990.

Борисова, Елена Г. «Проблема выбора вида (прагматическая точка зрения)». [В:] М. Ю. Черткова (отв. ред.). Труды аспектологического семинара филологического факультета МГУ им. М. В. Ломоносов 3. Москва: Изд-во МГУ, 1997, 18-26.

Бунина, Ирина К.. Система времен старославянского глагола. Москва: Изд-во АН CCCP, 1959.

Вимер, Бьорн. «Употребление совершенного вида в перформативном настоящем». [B:] Н. Н. Казанский (отв. ред.). Acta linguistica Petropolitana. Труды Института лингвистических исследований РАН. Т. Х. Ч. 3: Studia typologica octogenario Victori Khrakovskij Samuelis filio dedicate. Санкт-Петербург: Наука, 2014, 90-113.

Виноградов, Виктор В. Русский язык (грамматическое учение о слове). Изд. 2-е. Москва: Высшая школа, 1972 (Изд. 1-е 1947).

Војводић, Дојчил. „Транспозиција перфективног презента у руском и хрватскосрпском језику“. Зборник Матице српске за славистику 36, 1989: 85-97.

Војводић, Дојчил. „Глаголска (темпорална) метафора као средство за исказивање футуралности у српском, руском и пољском језику“. Годишњак Филозофског
О видско-временској синонимији и метафори у српском, руском и другим.

факултета у Новом Саду XXIV, 1996: 169-179.

Войводич, Дойчил. „Русский и сербско-хорватский перфективный презенс в сопоставительном аспекте“. Зборник Матице српске за славистику 54-55, 1998а: 119-147.

Војводић, Дојчил. „Futurum effectivum у словенским језицима“. Славистика II, 1998б: 45-52.

Войводич, Дойчил П. «Некоторые вопросы сопоставительной аспектологии в современной русистике и славистике». [В:] Б. Станкович (отв. ред.). Состояние и перспективы сопоставительных исследований русского и других языков: (Доклады). V Международный симпозиум МАПРЯЛ (Белград - Ниш, 30 мая 1 июня 2000 г.). Београд: Славистичко друштво Србије - Филолошки факултет, $2000,167-175$.

Войводич, Дойчил П. «Теория глагольной вневременности К. С. Аксакова и категория совершенного вида в русском и других славянских языках». [В:] Т. Н. Дорожкина (отв. ред.). Аксаковские чтения: духовное и литературное наследие семьи Аксаковых I. Материалы Междунар. науч.-практ. конф. (Уфа, 28-29 сентября 2001 г.). Уфа: Изд-во Башкир. ин-та развития образования, 2001, 18-23.

Војводић, Дојчил. „О видско-временској ‘конкуренцији’ у српском и другим словенским језицима“. [У:] Б. Остојић (ур.). Пети лингвистички скуп «Бошковићеви дани»: «Конкуренција језичких средстава и језичка норма» (Подгорица, 10-11. октобар 2002). Подгорица: ЦАНУ, 2003, 139-164.

Войводич, Дойчил П. «К вопросу о взаимозамене СВ и НСВ в русском и других славянских языках». [В:] Н. А. Тупикова (отв. ред.). Теоретические и лингводидактические проблемы исследования русского и других славянских языков. Волгоград: Изд-во ВолГУ, 2008, 101-115.

Войводич, Дойчил П. «Об употреблении и значении совершенного вида в перформативных предложениях-высказываниях в славянских языках: опыт типологической дифференциации». [В:] О. И. Сгибнева, Н. А. Тупикова (отв. ред.) Славянские языки: единицы, категории, ценностные константы. Волгоград: Издво ВолГУ, 2010, 175-191.

Войводич, Дойчил. «Славянский презенс-футурум совершенного вида в отрицательно-вопросительном контексте». [В:] Р. Бенаккьо (ред.). Глагольный вид: грамматическое значение и контекст / Verbal Aspect: Grammatical Meaning and Context [Die Welt der Slawen: Sammelbände / Сборники, Bd. 56; Hrsg. von P. Rehder und I. Smirnov]. München - Berlin - Washington/D.C.: Verlag Otto Sagner, 2015a, 573-583.

Войводич, Дойчил П. «Эффективный презенс или эффективный футурум? (К вопросу о типологии славянских перформативов совершенного вида)». [В:] М. Китадзё (сост.). Аспектуальная семантическая зона: типология систем и сценарии диахронического развития. Сборник статей $\mathrm{V}$ Международной конференции Комиссии по аспектологии Международного комитета славистов (Киото, 13-15 ноября 2015 г.). Киото: Издательство «Tanaka Print» (Университет Киото Сангё), 2015б, 27-33.

Воронец, Мария В. «Выбор глагола в условиях конкуренции видов». Вестник Томского государственного университета, 401, 2015: 21-25.

Гловинская, Марина Я. Многозначность и синонимия в видо-временной системе русского глагола. Москва: «Русские словари» - «Азбуковник», 2001.

Гренн, Атле, Филюшкина Краве, Мария. «Конкуренция видов: прагматические им- 
38

Дојчил П. Војводић

пликатуры и анафорические пресуппозиции несовершенного вида». Вопрось языкознания 4, 2007: 51-62.

Грубор, Ђуро. Аспектна значења [Посебни отисак из Рада ЈАЗУ 293, 295]. Загреб: JАЗУ, 1953.

Гуляницкий, Лев. «О некоторых случаях ‘конкуренции' глагольных видов». Russian Language Journal XXXII/113, 1978: 21-30.

Ермоленко, Сергей С. Образные средства морфологии. Киев: Наукова думка, 1987.

Зализняк, Андрей А. «Презенс совершенного вида в значении 'презенса напрасного ожидания'». [В:] В. Л. Янин, А. А. Зализняк. Новгородские грамоты на бересте (Из раскопок 1984-1989 гг.). Москва: Наука, 1993, 275-279.

Ивић, Милка. „Систем личних глаголских облика за обележавање времена у српскохрватском језику“. Годишњак Филозофског факултета у Новом Саду III, 1958: 139-152.

Ивић, Павле. „Систем значења основних претериталних времена у говору Галипољских Срба“. Јужнословенски филолог XX/1-4, 1953-1954: 229-262.

Исаченко, Александр В. Грамматический строй русского языка в сопоставлении с словацким: Морфология. Ч. 2. Братислава: Изд-во Словацкой АН, 1960.

Климонов, Владимир Д. «Взаимодействие модальности и аспектуальности в современном русском языке». Вестник Нижегородского университета им. Н. И. Лобачевского: Филология 6/2, 2011: 262-265.

Маслов, Юрий С. Избранные труды: Аспектология. Общее языкознание. Москва: Языки славянской культуры, 2004.

Мелиг, Ханс Роберт. "Дискурсивная функция глагольного вида при отрицании в русском языке». [В:] М. Китадзё (сост.). Аспектуальная семантическая зона: типология систем и сценарии диахронического развития. Сборник статей V Международной конференции Комиссии по аспектологии Международного комитета славистов (Киото, 13-15 ноября 2015 г.). Киото: Издательство «Tanaka Print» (Университет Киото Сангё), 2015, 142-150.

Меркулова, Мария Г. Морфологическая транспозиция в современном русском языке. Автореф. дисс. на соиск. уч. ст. канд. филол. наук. Москва: РУДН, 1997.

Недић, Јелена. „Глаголски облици у итеративним конструкцијама у руском и српском језику“. Славистика XXII, 2018: 110-122.

Падучева, Елена В. «О так называемой конкуренции видов». [В:] Е. В. Падучева. Семантические исследования: (Семантика времени и вида в русском языке. Семантика нарратива). Москва: Школа «Языки русской культуры», 1996, 53-65.

Падучева, Елена В. «Имперфектив отрицания в русском языке». Вопросы языкознания 3, 2008, 3-21

Петрухина, Елена В. «К вопросу о нейтрализации видового противопоставления». Československá rusistika XXI/4, 1976, 174-178.

Петрухина, Елена В. «О функционировании видового противопоставления в русском языке в сопоставлении с чешским (при обозначении повторяющихся действий)». Русский язык за рубежом 1, 1978, 57-60.

Петрухина, Елена В. «Функционирование презентных форм глаголов совершенного и несовершенного вида (с точки зрения взаимодействия грамматических категорий вида и времени) в чешском языке в сопоставлении с русским». [В:] А. Г. Широкова, Вл. Грабье (ред.). Сопоставительное изучение грамматики и лексики русского языка с чесшским языком и другими славянскими языками. Москва:
О видско-временској синонимији и метафори у српском, руском и другии ..

Изд-во Моск. ун-та, 1983, 152-172.

Петрухина, Елена В. Аспектуальные категории глагола в русском языке в сопоставлении с чешским, словацким, польским и болгарским языками. Москва: Изд-во МГУ, 2000.

Петрухина, Елена В. «Дискуссионные вопросы изучения русского глагольного вида». [In:] A. Nagórko, S. Heyl, E. Graf(Hrsg.). Sprache und Gesellschaft: Festschrift fur Wolfgang Gladrow [Berliner Slawistische Arbeiten, Bd. 33]. Frankfurt am Main - Berlin: Peter Lang, 2008, 224-239. URL: http://www.philol.msu.ru/ ruslang/pdfs petrukhina-ev_8_diskussionnie_voprosi_gladr.pdf (25.11.2018).

Петрухина, Елена В. Русский глагол: категории вида и времени (в контексте современных лингвистических исследований). Учебное пособие. Москва: МАКС Пресс, 2009

Петрухина, Елена В. «Интерпретация видовых различий между русским, чешским и словенским языками». Slavistična revija 67/1, 2019: 31-49.

Пешковский, Александр М. Русский синтаксис в научном освещении. Изд. 8-е. Москва: Эдиториал УРСС, 2001.

Пипер, Предраг. „Обележавање просторних односа предлошко-падежним конструкцијама у савременом руском и савременом српскохрватском књижевном језику“. Прилози проучавању језика, 13-14, 1978: 1-51.

Пипер, Предраг. Заменички прилози у српскохрватском, руском и пољском језику: (Семантичка студија) [Библиотека Јужнословенског филолога, нова серија, Књ. 8]. Београд: Институт за српскохрватски језик, 1988.

Пипер, Предраг. „Временске транспозиције и заменичке речи у српскохрватском и другим словенским језицима“. Научни сасатанак слависта у Вукове дане 14/2, 1985: 51-58.

Пипер, Предраг, Иван Клајн. Нормативна граматика српског језика. Нови Сад: Матица српска, 2013.

Плунгян, Владимир А. Общая морфология: Введение в проблематику. Учебное пособие. Изд. 2-е, испр. Москва: Едиториал УРСС, 2003 (Изд. 1-е 2000).

Попович, Людмила В. «Настоящее историческое глаголов несовершенного и совершенного видов в таксисных конструкциях сербского языка». [В:] М. Китадзё (сост.). Аспектуальная семантическая зона: типология систем и сценарии диахронического развития. Сборник статей V Международной конференции Комиссии по аспектологии Международного комитета славистов (Киото, 13-15 ноября 2015 г.). Киото: Издательство «Tanaka Print» (Университет Киото Сангё), 2015, 200-206.

Потебня, Александр А. Из записок по русской грамматике. T. IV: Глагол. Изд. 2-е. Москва: Просвещение, 1977 (Изд. 1-е 1941).

Прокопович, Елена Н. Глагол в предложении: (Семантика и стилистика видо-временных форм). Москва: Наука, 1982.

Ремчукова, Елена Н. «Понятие транспозиции, ее разновидности и функции в современном русском языке». Труды по русской и славянской филологии Лингвистика. Новая серия [Тарту] 1, 1997: 154-172.

Савић, Свенка. „Из прагматике глаголских облика у српскохрватском језику: употреба презента и перфекта у приповедању“. Научни састанак слависта у Вукове дане 14/2, 1985: 87-95.

Семиколенова, Елена И. «Избирательность в употреблении вида глагола как следствие процесса нейтрализации». Культура народов Причерноморья 37, 2003: 176-182. 
Славкова, Светлана. «Перформативное употребление глаголов просить/попросить и моля/помоля в русском и болгарском языках: прагматическая роль вида и времени». Scando-Slavica 60/2, 2014: 231-252.

Стевановић, Михаило. Савремени српскохрватски језик: (Граматички системи и књижевнојезичка норма). Књ. II: Синтакса. Београд: Научна књига, 1969.

Стојићевић, Александар. Значење аориста и имперфекта у српскохрватском језику. Љубљана: САЗУ, 1951

Танасић, Срето. Презент у савременом српском језику. Београд: Институт за српски језик САНУ, 1996

Тошович, Бранко. Экспрессивный синтаксис глагола русского и сербского/хорватского языков. Москва: Языки славянской культуры, 2006.

Тху Ха, Буй. «Конкуренция видов в русском нарративном тексте (проблема ее передачи на вьетнамский язык)». Филологические науки. Вопросы теории и практики [Тамбов: Грамота] 6/36 (в 2-х ч. Ч. I), 2014: 37-39. <www.gramota.net materials $/ 2 / 2014 / 6-1 / 9 \mathrm{html}>31.03 .2019$.

Фичи Джусти, Франческа. «Об употреблении презенса совершенного вида и о значении форм будущего времени в 'Житии протопопа Аввакума'». [В:] Т. М. Николаева (отв. ред). Русистика. Славистика. Индоевропеистика. Сборник к 60-летию А. А. Зализняка. Москва: «Индрик», 1996, 311-319.

Черткова, Марина Ю. Грамматическая категория вида в современном русском языке. Москва: МГУ, 1996.

Шведова, Лилия Н. Трудные случаи функционирования видов русского глагола: (К проблеме конкуренции видов). Москва: Изд-во МГУ, 1984.

Bareš, Karel. "O konkurenci vidů v českém a ruském jazyce". Časopis pro slovanské jazyky, literaturu a dějiny SSSR 4, 1956: 566-579.

Benacchio, Rosanna. "Конкуренция видов, вежливость и этикет в русском имеперативе”. Russian Linguistics 26/2, 2002: 149-178.

Benacchio, Rosanna. Вид и категория вежливости в славянском императиве: сравнитльный анализ [Slavistische Beiträge, Bd. 472]. München - Berlin: Verlag Otto Sagner, 2010.

Derganc, Aleksandra. „Несколько заметок в связи с перформативными глаголами в русском и словенском языках“. Filologija 20-21, 1993: 67-75.

Derganc, Aleksandra. "Iaz ze zaglagolo Zlodeiu (K vprašanju glagolskega vida v performativnih izjavah v slovanskih jezikih)". [In:] J. Kos et al. (red.) Zbornik Brižinski spomeniki. Ljubljana: Znanstvenoraziskovalni inštitut SAZU, 1996, 185-192.

Derganc, Aleksandra. "Einige Unterschiede im Gebrauch des perfektiven bzw. des imperfektiven Präsens im Russischen und Slowenischen". [In:] D. Huber, E. Worbs (Hgg.). Ars transferendi: Sprache, Übersetzung, Interkulturalität. Frankfurt am Main Berlin - Bern - New York - Paris - Wien: Peter Lang Verlag, 1998, 55-63.

Derganc, Aleksandra. "Nekatere razlike v rabi dovršnega oz. nedovršnega vida v ruščini in slovenščini”. Slavistična revija [Zbornik referatov za trinajsti mednarodni slavističn kongres (Ljubljana, 15.-21. avgusta 2003)], 51/poseb. št., 2003: 67-79.

Dickey, Stephen M. Parameters of Slavic Aspect: A Cognitive Approach. Stanford: CSLI Publications, 2000.

Forsyth, James. A Grammar of Aspect: Usage and Meaning in the Russian Verb [Studies in the Modern Russian Language, Extra Volume]. Cambridge: University Press, 1970.
О видско-временској синонимији и метафори у српском, руском и другим.

Grønn, Atle "Information Structure and Aspectual Competition". [In:] B. Gyuris, L. Kálmán, C. Piñón, \& K. Varasdi (eds.). Proceedings of the Ninth Symposium on Logic and Language. Budapest: Hungarian Academy of Sciences \& Eötvös Loránd University, 2006, 70-77.

Israeli, Alina. "Discourse Analysis of Russian Aspect: Accent on Creativity". Journal of Slavic Linguistics 4/1, 1996: 8-49.

Israeli, Alina. "Speaker's Attitudes, Goals and Aspectual Choices in WH- Questions". Le Langage et l'Homme XXXIII/1, 1998: 55-77.

Israeli, Alina."Les verbes de movement au présent scénique [Использование глаголов движения в значении настоящего сценического]". [In:] T. Milliaressi (éd.). La relation temps/aspect: approches typologique et contrastive [Collection UL3: travaux et recerches]. Lille: Université Charles-de-Gaulle-Lille 3, 2018, 385-392.

Ivić, Milka. „Načini na koje slovenski glagol ovremenjuje ponavljanu radnju“. [In:] M. Ivić. Lingvistički ogledi. Beograd: Prosveta (Biblioteka XX vek, Knj. 61), 1983, 37-56.

Ivić, Milka. O Vukovom i vukovskom jeziku. 2., dop. izd. Zemun: Biblioteka XX vek Beograd: Čigoja štampa, 1997.

Kalsbeek, Janneke, Radovan Lučić. „Oblik kondicionala u funkciji označavanja ponavljane radnje u prošlosti“. Croatica et Slavica Iadertina IV, 2008: 7-21.

Koschmieder, Erwin. Nauka o aspektach czasownika polskiego w zarysie: Próba syntezy [Rozpravy i materjały wydziału I Towarzystwa przyjacioł nauk w Wilnie V/2]. Wilno: Nakładem Towarzystwa przyjaciół nauk, 1934

Kravar, Miroslav. „Aspektne osobitosti modalnih glagola (na hrvatskosrpskom materijalu)“. Radovi Filozofskog fakulteta u Zadru 5, 1964: 35-48.

Křížková, Helena. "Ke konkurenci vidů v ruštině a češtině". Československá rusistika $\mathrm{VI} / 1,1961: 32-38$

Křížková, Helena. "Pojetí neutralizace v morfologii". Slovo a slovesnost XXVI/1, 1965 $14-23$

Mathesius, Vilém. "O konkurenci vidů v českém vyjadřování slovesném". [In:] V. Mathesius. Čeština a obecný jazykozpyt: soubor statí [Czech Language and General Linguistics. Selected Papers]. Praha: Melantrich, 1947, 195-202.

Mazon, André. Emplois des aspects du verbe russe. Paris: Librairie ancienne Honoré Champion, 1914.

Miklosich, Franc. Vergleichende Grammatik der slavischen Sprachen. Band IV: Syntax Manulneudruck der Erstausgabe von 1868-1874 (Wien: Braumüller). Heidelberg: Carl Winters Universitätsbuchhandlung, 1926.

Musić, August. "Zum Gebrauche des Praesens verbi perf. im Slavischen". Archiv für slavische Philologie 24, 1902: 479-514.

Musić, August. „Značenje perfektivnoga prezenta u negativnim pitanjima u hrvatskom ili srpskom jeziku“. Јужнословенски филолог I, 1913: 27-34.

Musić, August. „Slovenski efektivni prezenat“. Rad JAZU 253, 1935: 165-180.

Panzer, Baldur. Die Funktion des Verbalaspekts im Praesens historicum des Russischen [Slavistische Beiträge, Bd. 9]. München: Otto Sagner, 1963.

Popovic, Ljudmila. "Usage performatif des formes verbales à sens perfectif dans les langues slaves [Перформативное употребление глагольных форм перфектной семантики в славянских языках]". [In:] T. Milliaressi (éd.). La relation temps/aspect: approches typologique et contrastive [Collection UL3: travaux et recerches]. Lille: Université Charles-de-Gaulle - Lille 3, 2018, 269 -276.

Славистика XXIII/1 (2019) 
Radovanović, Milorad. Spisi iz sintakse i semantike. Sremski Karlovci: Izdavačka knjižarnica Zorana Stojanovića - Novi Sad: Dobra vest (Biblioteka Theoria), 1990.

Rassudova, Olga P. Aspectual Usage in Modern Russian. Moscow: Russky Yazyk, 1984. Rathmayr, Renate. Die perfektive Präsensform im Russischen: Eine multilateralkontrastive Funktionsanalyse der russischen Form anhand ihrer französischen und deutschen Entsprechungen. Wien: Verlag der Österreichischen Akademie der Wissenschaften, 1976.

Škrabec, Stanislav. "Zum Gebrauche der Verba perfectiva und imperfectiva im Slovenischen". Archiv für slavische Philologie 25, 1903: 554-564.

Škrabec, Stanislav. "Praesens effectivum". Cvetje z vertov sv. Frančiška XXIII/7 (1906); XXVII/10, 11, 12 (1910); XXVIII/1, 5, 7, 9, 10, 11, 12 (1911); XXIX/1, 3, 4, 5, 6, 7 (1912) [1906-1912].

Tošović, Branko. Korelaciona sintaksa: projekcional. Graz: Institut für Slavistik der KarlFranzens-Universität Graz, 2001

Vojvodić, Dojčil. „Upotreba perfektivnog prezenta u značenju sadašnjosti u ruskom, hrvatskosrpskom i ostalim slavenskim jezicima (?)“. Radovi Filozofskog fakulteta u Zadru 27/17, 1988: 49-60.

Vojvodič, Dojčil. "Le présent narratif perfectif : analyse comparative du serbe et du russe [Сербское и русское настоящее историческое СВ в сопоставительном аспекте]”. [In:] T. Milliaressi (éd.). La relation temps/aspect: approches typologique et contrastive [Collection UL3: travaux et recerches]. Lille: Université Charles-de-Gaulle - Lille 3 , 2018, 71-80.

Žagar, Igor Ž. Zagatnost performativnosti ali kako obljubiti. Ljubljana: Državna založba Slovenije, 1989.

\section{Извори}

Андрић, Иво. Проклета Авлија [И. Андрић. Сабрана дела, књ. IV]. Београд: Просвета - Загреб: Младост - Сарајево: Свјетлост - Љубљана: Државна заложба Словеније, 1963.

Андрич, Иво. «Проклятый двор» (перевод Т. Поповой). [В:] Повести и рассказы югославских писателей. Москва: Худож. лит., 1978, 15-87.

Булгаков, Михаил А. Избранное: Роман «Мастер и Маргарита». Рассказы. Москва: Худож. лит., 1982.

Булгаков, Михаил. Мајстор и Маргарита (превео М. Чолић) [М. Булгаков. Дела: Четврта књига]. Београд: Народна књига, 1985.

Вуковић, Чедо. Мртво Дубоко. Сарајево: Свјетлост, 1959.

Добрович, Анатолий Б. «Психотерапевт из дома напротив (информация с четырьмя отступлениями)». Знание - сила 2, 1974: 59-61.

Зола, Емил. Жерминал (превео Д. Матић). Нови Сад: Матица српска - Београд: Рад, 1974.

Золя, Эмиль. Западня. Жерминаль (перевод Е. Шишмаревой, О. Моисеенко и $\mathrm{H}$ Немчиновой). Москва: Худож. лит., 1988.

Исаковић, Антоније. „Погреб“. [У:] А. Исаковић. Приповетке. Београд: Српска књижевна задруга, 1964.
О видско-временској синонимији и метафори у српском, руском и другим

Исакович, Антоние. «Погребение» (перевоп Т. Поповой). [В:] Повести и рассказь югославских писателей. Москва: Худож. лит., 1978, 389-397.

Лалић, Михаило. Лелејска гора. Београд: Нолит, 1975.

Лалич, Михаило. Лелейская гора (перевод Т. Вирты). Београд: Нолит, 1977.

Маринковић, Ранко. Глорија. Београд: Нолит, 1966.

Маринкович, Ранко. «Глория. Миракль» (перевод Н. Лебедевой и А. Михеевой). [В:] Р. Маринкович. Избранное. Москва: Худож. лит., 1974.

Михаиловић, Драгослав. „Увеличане слике и досадне мачке“. [У:] Д. Михаиловић. Петријин венац. Београд: Српска књижевна задруга, 1975

Михаилович, Драгослав. «Увеличенные фотографии и надоевшие кошки» (перевод О. Кутасовой). [В:] Повести и рассказы югославских писателей. Москва: Худож. лит., 1978, 576-598.

Новак, Слободан. «Помолимся, подумаем...» (перевод А. Романенко). [В:] Повести и рассказы югославских писателей. Москва: Худож. лит., 1978, 398-402.

Панова, Вера Ф. Сережа. Москва: Русский язык, 1976.

Петровић, Растко. Људи говоре. Београд: Народна књига - Алфа, 1996.

Симонов, Константин М. Живые и мертвые, кн. І. Москва: Советский писатель, 1977. Симонов, Константин. Живи и мртви (превео Д. Мићовић). Београд: Нолит, 1962.

Толстой, Алексей Н. Петр Первый (роман в 3-х кн.). Москва: ОГИЗ - Гос. изд-во худож. лит., 1947.

Ћосић, Добрица. Далеко је сунце [Д. Ћосић. Сабрана дела, књ. прва]. Београд: Просвета - Сарајево: Свјетлост, 1966.

Чосич, Добрица. Солнце далеко (перевод Т. Поповой и А. Романенко). Москва: Издво иностранной литературы, 1956.

Фото Форум: http://www.photo-forum.net/forum/read.php?f=3\&i=328587\&t=328539 (15.11.2018)

Џекова, В. \& Т. Захов. Херсилија: Новела за толеранцијата, 2012; https://books. google.rs/books?id=hcX1AwAAQBAJ\&pg=PA33\&dq $=\% \mathrm{D} 0 \% 8 \mathrm{D} \& \mathrm{hl}=\mathrm{en} \& \mathrm{sa}=\mathrm{X} \&$ ei $=$ po LU f6LeeO4gTb84DQAw\&redir esc $=\mathrm{y} \# \mathrm{v}=$ onepage $\& \mathrm{q}=\% \mathrm{D} 0 \% 8 \mathrm{D} \& \mathrm{f}=$ false $(15.11 .201 \overline{8})$.

Andrić, Ivo. "Przeklęte Podwórze" (przełożył J. Wierzbicki). [In:] I. Andrić. Opowiadania o bracie Piotrze. Rozmowa z Goyą. Lódź: Wydawnictwo Lódzkie, 1977, 17-124.

Boulgakov, Mikhaïl. Le Maître et Marguerite (traduit par C. Ligny). Paris: Robert Laffont (Édition Le Livre de Poche), 1968 [1975].

Bułhakow, Michał. Mistrz i Małgorzata (tłumaczyli I. Lewandowska, W. Dąbrowski). Warszawa: Czytelnik, 1996

Dobrović, A[natolij]. Psihoterapeut iz kuće nasuprot (prevela L. Bakarić). Zagreb: Filozofski fakultet - Zavod za lingvistiku, 1977 [= Корпус научног пројекта „Контрастивна анализа сувременог руског и хрватског или српског књижевног језика“].

Novak, Slobodan. „U trećem otajstvu slavnome razmišljat ćemo“. [In:] S. Novak. Tvrdi grad: novele. Zagreb: Zora, 1961

Panowa, Wiera. Sierioża (tłumaczyła J. Dziarnowska). Warszawa: Czytelnik, 1986.

Simonov, Konstantin. Żywi i martwi (przełożył J. Brzęczkowski). Warszawa: Widawnictwo Ministerstwa Obrony Narodowej, 1984.

Zola, Emile. Germinal. Paris: Éditions J'ai Lu, 1978.

Zola, Emil. Germinal (przełożyła K. Dolatowska). Warszawa: Państwowy Instytut Widawniczy, 1987.

Славистика XXIII/1 (2019) 


\section{Дойчил П. Войводич}

\section{К ВОПРОСУ О ВИДО-ВРЕМЕННОЙ СИНОНИМИИ И МЕТАФОРЕ В СЕРБСКОМ, РУССКОМ И ДРУГИХ СЛАВЯНСКИХ ЯЗЫКАХ}

\section{Резюме}

В предлагаемой работе рассматривается в сопоставительном аспекте (на материале сербского, русского и других славянских языков) функционирование морфологически противопоставленных друг другу категорий совершенного (CB) и несовершенного видов (HCB) в условиях так называемой конкуренции, соответственно в одном и том же синтаксическом контексте. Отмечается, что использование взаимозамены (конкуренции, синонимии) видов является общей характеристикой славянских языков, и они в этом отношении во многом совпадают, но не все они способны однозначно и в одинаковой степени синтаксически выразить данное противопоставление. Это связано с тем, что одни языки (севернославянские и словенский) пользуются большей свободой взаимозамены видов, в то время как в других (в южнославянских, в том числе и в сербском) эта возможность в некоторых случаях очень ограничена, или даже полностью отсутствует. Обращается внимание на то, что данное явление чаще всего реализуется в формах изъявительного наклонения, в первую очередь, в презентных формах СВ и НCB, и что НCВ по сравнению с СВ все-таки обладает более широкими возможностями видовой субституции (конкуренции). Рассматривая конкуренцию видов, где СВ и НСВ относительно равноправно взаимозаменяются, автор уделяет внимание и другим сходным явлениям, в первую очередь, нейтрализации видового противопоставления (особенно характерной для русского языка), связанной с транспозицией НСВ, подразумевающей метафорическое расширение семантики и увеличение числа функций НСВ за счет СВ. Подчеркивается, что во всех типах анализируемых примеров решающую роль играет как лексическое значение глаголов и актуализация их видо-временных форм, так и контекст, в котором они употребляются.

Ключевые слова: синонимия (субституция, взаимозамена, конкуренция) СВ и НСВ, видо-временная транспозиция (метафора), видовая нейтрализация, сербский, русский и другие славянские языки, сопоставительный аспект. 